\title{
Antidepressant Drugs Effects on Blood Pressure
}

\author{
Anna Calvi ${ }^{1}$, Ilaria Fischetti ${ }^{1}$, Ignazio Verzicco ${ }^{1}$, Martino Belvederi Murri ${ }^{2}$, \\ Stamatula Zanetidou ${ }^{3}$, Riccardo Volpi ${ }^{1}$, Pietro Coghi ${ }^{1}$, Stefano Tedeschi ${ }^{1}$, Mario Amore ${ }^{4}$ \\ and Aderville Cabassi ${ }^{1 *}$

\begin{abstract}
${ }^{1}$ Cardiorenal and Hypertension Research Unit, Physiopathology Unit, Clinica Medica Generale e Terapia Medica, Department of Medicine and Surgery (DIMEC), University of Parma, Parma, Italy, ${ }^{2}$ Department of Neuroscience and Rehabilitation, Institute of Psychiatry, University of Ferrara, Ferrara, Italy, ${ }^{3}$ Research Group on Mental and Physical Health of the Elderly (ARISMA), Bologna, Italy, ${ }^{4}$ Section of Psychiatry, Department of Neuroscience, Ophthalmology, Genetics, and Infant-Maternal Science, Istituti di Ricovero e Cura a Carattere Scientifico (IRCCS) Ospedale Policlinico San Martino, University of Genoa, Genoa, Italy
\end{abstract}

OPEN ACCESS

Edited by:

Guido laccarino,

University of Naples Federico II, Italy

Reviewed by:

Mauro Cataldi,

University of Naples Federico II, Italy Amelia Filippelli,

University of Salerno, Italy

Elise Peery Gomez-Sanchez,

University of Mississippi Medical

Center, United States

Annalisa Capuano,

University of Campania Luigi

Vanvitelli, Italy

${ }^{*}$ Correspondence:

Aderville Cabassi

aderville.cabassi@unipr.it

Specialty section:

This article was submitted to

Hypertension,

a section of the journal

Frontiers in Cardiovascular Medicine

Received: 02 May 2021

Accepted: 28 June 2021

Published: 03 August 2021

Citation:

Calvi A, Fischetti I, Verzicco I,

Belvederi Murri M, Zanetidou S, Volpi R, Coghi P, Tedeschi S, Amore M and Cabassi A (2021) Antidepressant

Drugs Effects on Blood Pressure.

Front. Cardiovasc. Med. 8:704281.

doi: 10.3389/fcvm.2021.704281
Individuals suffering from depressive disorders display a greater incidence of hypertension compared with the general population, despite reports of the association between depression and hypotension. This phenomenon may depend, at least in part, on the use of antidepressant drugs, which may influence blood pressure through different effects on adrenergic and serotoninergic pathways, as well as on histaminergic, dopaminergic, and cholinergic systems. This review summarizes extant literature on the effect of antidepressant drugs on blood pressure. Selective serotonin reuptake inhibitors are characterized by limited effects on autonomic system activity and a lower impact on blood pressure. Thus, they represent the safest class-particularly among elderly and cardiovascular patients. Serotonin-norepinephrine reuptake inhibitors, particularly venlafaxine, carry a greater risk of hypertension, possibly related to greater effects on the sympathetic nervous system. The norepinephrine reuptake inhibitor reboxetine is considered a safe option because of its neutral effects on blood pressure in long-term studies, even if both hypotensive and hypertensive effects are reported. The dopamine-norepinephrine reuptake inhibitor bupropion can lead to blood pressure increases, usually at high doses, but may also cause orthostatic hypotension, especially in patients with cardiovascular diseases. The norepinephrine-serotonin modulators, mirtazapine and mianserin, have minimal effects on blood pressure but may rarely lead to orthostatic hypotension and falls. These adverse effects are also observed with the serotonin-reuptake modulators, nefazodone and trazodone, but seldomly with vortioxetine and vilazodone. Agomelatine, the only melatonergic antidepressant drug, may also have limited effects on blood pressure. Tricyclic antidepressants have been associated with increases in blood pressure, as well as orthostatic hypotension, particularly imipramine. Oral monoamine-oxidase inhibitors, less frequently skin patch formulations, have been associated with orthostatic hypotension or, conversely, with hypertensive crisis due to ingestion of tyramine-containing food (i.e., cheese reaction). Lastly, a hypertensive crisis may complicate antidepressant treatment as a part 
of the serotonin syndrome, also including neuromuscular, cognitive, and autonomic dysfunctions. Clinicians treating depressive patients should carefully consider their blood pressure status and cardiovascular comorbidities because of the effects of antidepressant drugs on blood pressure profiles and potential interactions with antihypertensive treatments.

Keywords: arterial hypertension, orthostatic hypotension, selective serotonin reuptake inhibitors, serotoninnorepinephrine reuptake inhibitors, dopamine-norepinephrine reuptake inhibitor, tricyclic and tetracyclic antidepressants, monoamine oxidase inhibitors

\section{INTRODUCTION}

The World Mental Health Survey estimates that depression affects 322 million people worldwide with an overall prevalence of $4.4 \%$ while being higher in older age groups with more than $7.5 \%$ in females and $5.5 \%$ in males aged $55-75$ years (1). Depressive disorders range from $22.5 \%$ in Afghanistan to $2.5 \%$ in Japan, with the United States, Italy, France, and Germany lower than 5\%, Switzerland 6.2\%, and China and the United Kingdom around 3\% (2).

Depressed patients display a higher incidence of hypertension compared with the general population $(3,4)$. The risk seems almost double among Caucasians and African Americans (5). Females have a major prevalence of the depressive disorder, but depressed men are at higher risk of developing hypertension, possibly because of an unhealthier lifestyle $(1,6,7)$. Fertile women carry a lower risk vs. postmenopausal women, suggesting the involvement of sex hormones, further confirmed by the similar risk between postmenopausal women and men (8).

The increase in blood pressure (BP) among depressed individuals may involve several mechanisms, including endothelial dysfunction, low-grade inflammation, hypercoagulation (9-11), altered hypothalamic-pituitaryadrenal axis (3), and systemic autonomic dysfunction with sympathetic activation prevailing over parasympathetic drive $(4,12)$. Depressed patients may be less inclined to follow proper lifestyle recommendations and less adherent to antihypertensive and other drug therapies. However, major depression is not only associated with hypertension but also modest, while not significant, BP increases (13-15) or decreases have been previously reported in depressed patients $(16,17)$. Another possible reason for $\mathrm{BP}$ level abnormalities in depressed individuals is the use of antidepressant drugs, which can affect BP levels by inducing hypertension, hypotension, and orthostatic hypotension. This represents a critical issue for patients and clinicians, whether psychiatrists, internists, cardiologists, or family doctors. Several classes of antidepressant drugs may affect BP through various mechanisms, e.g., altering neural pathways involved in the vascular tone control, cardiac heart rate (HR) automatisms, or conduction mechanisms.

Given these premises, this review aims to discuss the effects on BP associated with antidepressant drugs, including selective serotonin reuptake inhibitors (SSRIs), serotonin-norepinephrine reuptake inhibitors (SNRIs), selective norepinephrine reuptake inhibitors, dopamine (DA)-norepinephrine reuptake inhibitors, norepinephrine-serotonin modulators, serotonin agonist/antagonist-reuptake inhibitors, tricyclic and tetracyclic antidepressants (TCAs), and monoamine oxidase inhibitors (MAOIs), underscoring their pharmacological properties and how this information can be used in clinical practice.

\section{METHODS}

An extensive review of English language literature was performed to identify all relevant articles describing the BP changes induced by antidepressant drugs. We searched PubMed, EMBASETM, CINHAL, Web of Science, and Cochrane databases for relevant articles. Related search terms were used as follows: ("blood pressure, arterial hypertension" [Mesh]) OR ("antidepressant drugs" [Mesh]) OR ("orthostatic hypotension" [Mesh]) OR ("arterial hypotension" [Mesh]) OR ("major depression" [Mesh]) OR ("depressive disorders" [Mesh]) OR ("serotoninergic syndrome" [Mesh]) OR ("cheese reaction" [Mesh]) AND (“antihypertensive agents" [Mesh]) (Figure 1). Medical subject heading terms were used to enhance electronic searches. Hand searches of references identified additional studies of interest, and at least two reviewers independently reviewed each article for eligibility. We excluded conference proceedings. The search was last updated on April 26, 2021. The nomenclature of the drugs and their molecular targets conform to the recently published International Union of Basic and Clinical Pharmacology/British Pharmacological Society Guide to Pharmacology nomenclature classification (18).

\section{Cardiovascular Alterations in Depressive Disorders}

\section{Neurotransmitters Involved in Depression}

5-Hydroxytryptamine (5-HT) plays a major role in the pathogenesis of depressive disorders through its action on the central nervous system, whereas it also influences the peripheral cardiovascular system. 5-HT can act on multiple pathways, including the central and peripheral autonomic nervous systems, kidney sodium and water balance, and adrenal gland hormone secretion, all of which are involved in short- and long-term BP control. 5-HT effects on BP are various and start via a direct arterial constriction but also include different responses depending on the type of vascular bed and on the activation of 5$\mathrm{HT}$ receptor subtypes. Vasoconstriction mainly relates to $5-\mathrm{HT}_{2 \mathrm{~A}}$ and $5-\mathrm{HT}_{1 \mathrm{~B} / 1 \mathrm{D}}$ receptor activation (19). The effects of $5-\mathrm{HT}$ on 


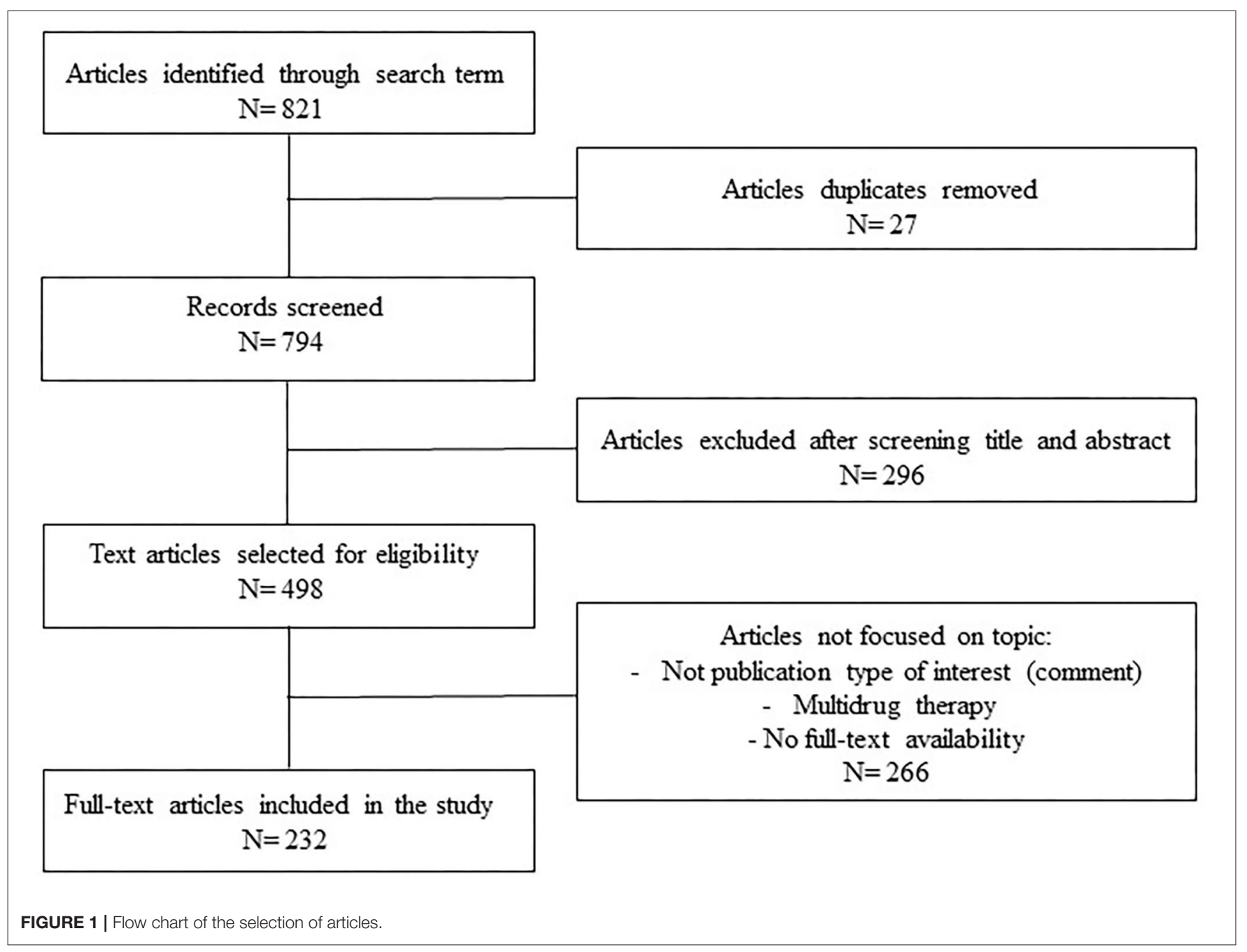

the heart are diverse; on one side, a positive inotropic, lusitropic, and pro-arrhythmic effect is reported in humans; on the other, it can induce bradycardia by activating the parasympathetic drive and by inhibiting the release of norepinephrine (NE) (20). 5-HT also has direct renal anti-diuretic and anti-natriuretic effects, leading to increased extracellular volume (19). 5-HT also affects BP control by increasing salt and water reabsorption by stimulating cortisol and aldosterone secretion and facilitating epinephrine release from the adrenal medulla (21). Both 5-HT excitatory and inhibitory effects on the central and peripheral autonomic nervous systems have been described. 5-HT-related $\mathrm{BP}$ rise may depend on the central stimulation of the 5$\mathrm{HT}_{2 \mathrm{~A}}$ receptor, the rise of sympathetic activity, and vasopressin release (22), but it is buffered by $5-\mathrm{HT}_{1 \mathrm{~A}}$-mediated sympathetic inhibition and parasympathetic vagal activation leading to a fall in BP (23). NE is another neurotransmitter whose increased availability represents the target of the antidepressant treatment. In fact, in depression, NE deficit relates to decreased cognitive difficulties (i.e., decreased attention and concentration), low motivation, and low energy (24), whereas 5-HT deficit has been mainly linked to symptoms of anxiety, obsessions, suicide, and appetite disturbances (25). NE can increase BP through arterial postsynaptic $\alpha 1$-adrenergic receptor stimulation and causes positive myocardial chronotropic, inotropic, and lusitropic effects through a $\beta 1$-adrenergic receptor activation. The hypertensive effects of NE on postsynaptic $\alpha 1$-adrenergic receptors are only partially counterbalanced by presynaptic $\alpha 2$ adrenergic receptor stimulation, resulting in a reduced release of catecholamines. DA, the precursor of NE and epinephrine, is also involved in depression, particularly in specific neural circuit activities influencing reward prediction, motivational arousal, and responsiveness to conditioned incentive stimuli (26). In fact, several symptoms observed in depression, such as anhedonia and amotivation, are associated with DA deficit, particularly in the medial frontal cortical regions and in the amygdala (27). DA affects the cardiovascular system in a dose-dependent way: at a low dose, it acts on D1- and D2-like dopaminergic receptors located in the coronary mesenteric and renal arteries and tubules, resulting in local vasodilation and increased natriuresis without inducing a drop in systemic BP (28). At high doses, DA stimulates $\beta$-adrenergic receptors and induces positive cardiac inotropic and chronotropic effects. At very high doses, $\alpha 1$-adrenergic receptors 
are also activated by DA, determining systemic vasoconstriction and BP elevation.

\section{Vascular Abnormalities in Depression}

In the last decade, depression has been considered a risk factor for cardiovascular disease, independent of traditional risk factors $(29,30)$. Major depression in otherwise healthy patients is involved in the development of adverse cardiovascular events (31). The mechanisms that link depression and cardiovascular alterations are far from clear (32). Major depression has been associated in depressed adolescents with reduced parasympathetic and increased sympathetic tone (33). In depressed patients, there is substantial evidence showing alterations in the autonomic nervous system leading to a significant reduction in $\mathrm{HR}$ variability. $\mathrm{HR}$ variability is a widely recognized prognostic risk factor for adverse cardiovascular events, such as myocardial infarction and arrhythmias, and cardiac mortality $(12,32)$. In addition, because depressive disorders are characterized by chronic stress, levels of circulating cortisol are increased in the long term. In this setting, immune cells become insensitive to the regulatory effects of cortisol and contribute to the chronic inflammation seen in depressed patients (34). Cortisol also increases arterial contractile sensitivity to NE and suppresses the production of prostacyclin and nitric oxide in endothelial cells, thereby resulting in higher vascular resistance (35). In patients with major depression, an increase in blood viscosity can contribute to the elevation of systemic vascular resistance $(36,37)$. In addition to abnormalities in resistance arteries with a rise in systemic vascular resistance, alterations are also observed in large arteries (brachial) of depressed patients (38). Carotid intima-media thickness is increased in depressed patients as well as the carotid-femoral pulse way velocity (39), both known predictors of major cardiovascular events. It seems that antidepressant drugs can affect the progression of arterial stiffness; independently from an effect on BP, it has been observed that duloxetine, an SNRI, can accelerate vascular damage while the SSRI escitalopram is neutral (40). Furthermore, a recent interesting report showed that 6-month treatments with the SSRI citalopram improved endothelial function and arterial stiffness (41).

\section{Antihypertensive Therapy and Depression}

Several pathogenetic mechanisms involved in BP regulation and the targets of effective and commonly prescribed antihypertensive drugs can be involved in the rise or reduction in depressive symptoms (42). Historically, patients treated with beta-adrenergic blockers have been considered at high risk for developing depression (43), and this is particularly relevant for lipophilic vs hydrophilic drugs and for nonselective drugs, as recently demonstrated $(43,44)$. However, a recent study based on Danish population registers showed amelioration of depressive symptoms in patients treated with propranolol, atenolol, bisoprolol, and carvedilol. Among the other antihypertensive drug classes, angiotensin-converting enzyme inhibitors (ramipril and enalapril) and calcium channel antagonists (amlodipine, verapamil alone, and verapamil combinations) also improved depressive symptoms (42) even if randomized clinical trials on renin-angiotensin system targeting agents and depression are lacking. Furthermore, it is also important to consider how the frequent concomitance of depression and arterial hypertension in patients should make us pay attention to the possible interactions between antihypertensive and antidepressant drugs. Table 1 reports the interactions between these two classes of drugs that involve both pharmacokinetic and pharmacodynamic mechanisms and that can cause serious adverse effects by enhancing or buffering the BP-lowering effect of antihypertensives, resulting in severe hypotension or bradycardia or in a BP rise.

\section{Selective Serotonin Reuptake Inhibitors}

SSRIs are most frequently used as first-line treatment of major depression (Table 1) (58). Their efficacy has also been demonstrated in the treatment of generalized anxiety, panic, social anxiety, and obsessive-compulsive disorders. This class includes citalopram, escitalopram, paroxetine, fluoxetine, fluvoxamine, and sertraline. Sertraline and paroxetine have also been approved for the treatment of post-traumatic stress disorder.

SSRIs selectively block presynaptic reuptake mediated by serotonin transporters (SERTs), thereby enhancing and prolonging serotonergic neurotransmission. Other effects of SSRIs are related to presynaptic serotonin $(5-\mathrm{HT})$ receptor desensitization, especially $5-\mathrm{HT}_{1 \mathrm{~A}}$, thus facilitating $5-\mathrm{HT}$ release (55). Free circulating 5-HT levels are highly variable, being mainly taken up by SERT in platelets (19). Sertraline, fluvoxamine, and paroxetine induce a 5-HT depletion of platelets after chronic treatment and an increase of 5-HT free circulating levels, potentially interfering with BP control (59). Another relevant effect of chronic SSRI treatment on the autonomic balance is represented by the increase in HR variability resulting in better clinical outcomes with reduced morbidity and mortality in patients with previous cardiac disease (Table 2) (12). Caution should be considered, especially among elderly patients in relation to SSRI-mediated vasopressin release, which might lead to the development of hyponatremia (60). Because of 5-HT-mediated pulmonary arterial vasoconstriction and smooth muscle cell proliferation, SSRIs used in the second half of pregnancy have been related to a higher risk of persistent pulmonary hypertension in newborns (61). In animal models, decreased BP levels are reported after long-term in vivo 5-HT administration, indicating 5-HT-mediated nitric oxide release as a mechanism involved in the fall in $\mathrm{BP}(18,62)$. This puzzling picture of potential 5-HT-related short- and long-term BP effects should be considered in patients treated with SSRIs.

\section{Citalopram, Escitalopram, and Paroxetine}

Chronic treatment with citalopram and escitalopram, its therapeutically active S-enantiomer, did not change systolic and diastolic BP levels (BP values varying between 0.3 and $<1$ $\mathrm{mmHg}$ ) nor HR neither QT interval length in two studies on elderly depressed patients, with and without coronary artery disease $(73,74)$. In a geriatric population of patients, citalopram was effective in further reducing $\mathrm{BP}$ when depressed and 
TABLE 1 | List of pharmacological characteristics of antidepressant drug class including therapeutic dose, half-life, metabolism, and antihypertensive drug interactions.

\begin{tabular}{|c|c|c|c|c|}
\hline Antidepressant & Therapeutic dose (starting, Mg) & Half-life (hours) & Cyp-450 metabolizer (S) & $\begin{array}{l}\text { Interactions with antihypertensive } \\
\text { drugs }\end{array}$ \\
\hline \multicolumn{5}{|l|}{ SSRI } \\
\hline Citalopram & $20-40(20)$ & $23-45$ & $3 \mathrm{~A} 4,2 \mathrm{C} 19$ & \\
\hline Escitalopram & $10-20(20)$ & $27-32$ & - & \\
\hline Paroxetine & $20-50(20)$ & 24 & 2D6 & $\begin{array}{l}\uparrow \text { Metoprolol (45-47), } \uparrow \text { Propranolol } \\
\text { (48) }\end{array}$ \\
\hline Fluoxetine & $20-80(20)$ & $48-72$ & 2D6, 3A4 & $\uparrow \beta$-Blockers (48-50) \\
\hline Fluvoxamine & 50-300 (50) & $9-28$ & $3 \mathrm{~A} 4,1 \mathrm{~A} 2,2 \mathrm{C} 9 / 2 \mathrm{C} 19$ & $\uparrow$ Carvedilol (51), $\downarrow$ Propranolol (50) \\
\hline Sertraline & 50-200 (50) & 22-36 & 2D6, 3A4 & $\uparrow$ Carvedilol (51) \\
\hline \multicolumn{5}{|l|}{ SNRI } \\
\hline Venlafaxine & 75-225, $\max 375$ (37.5) & 11 & 2D6, 3A4 & $\downarrow$ Metoprolol (52) \\
\hline Desvenlafaxine & $50-100(50)$ & $9-13$ & $3 \mathrm{~A} 4$ & \\
\hline Duloxetine & 40-60, $\max 120(40)$ & 12 & $2 \mathrm{D} 6,1 \mathrm{~A} 2$ & $\uparrow$ Metoprolol (52), $\uparrow$ Propranolol (48) \\
\hline Milnacipran & $30-200$ (12.5) & 8 & 3A4 & \\
\hline Levomilnacipran & $40-120(20)$ & 12 & $3 \mathrm{~A} 4$ & \\
\hline REBOXETINE & $4-8, \max 10(4)$ & 12 & $3 \mathrm{~A} 4$ & \\
\hline \multicolumn{5}{|l|}{ DNRI } \\
\hline Bupropion immediate, sustained, & 225-450 (75), 200-450 (100) & $8-10,12,24,21$ & 2B6 & $\begin{array}{l}\uparrow \text { Carvedilol (51), } \uparrow \text { Metoprolol (52), } \uparrow \\
\text { Propranolol (48) }\end{array}$ \\
\hline Extended release, hydrobromide & 150-450 (150), 174-522 (174) & & & \\
\hline \multicolumn{5}{|l|}{ NSM } \\
\hline Mirtazapine & $15-45(15)$ & $20-40$ & $2 \mathrm{D} 6,1 \mathrm{~A} 2$ & $\downarrow$ Clonidine (53) \\
\hline Mianserin & 30-60, max 90 (30) & $12-29$ & 2D6 & $\uparrow$ Prazosin (54) \\
\hline \multicolumn{5}{|l|}{ SARI } \\
\hline Nefazodone & $100-300(100)$ & $2-4$ & 3A4 & \\
\hline Trazodone & $150-600(150)$ & $3-6$ & $3 \mathrm{~A} 4$ & $\uparrow$ Clonidine $(55,56)$ \\
\hline Vortioxetine & $5-20(5)$ & 66 & 2D6,3A4,2C19,2C9,2A6,2C8, & \\
\hline Vilazodone & 20-40 (10) & 25 & 3A4, 2C19, 2D6 & \\
\hline AGOMELATINE & $25-50(25)$ & $1-2$ & $1 \mathrm{~A} 2$ & \\
\hline \multicolumn{5}{|l|}{ TCA } \\
\hline Imipramine & 50-150, max $300(25)$ & 19 & $2 \mathrm{D} 6,1 \mathrm{~A} 2$ & $\uparrow \beta$-Blockers $(49,57)$ \\
\hline Amitriptyline & $50-150, \max 300(25)$ & $10-28$ & $2 \mathrm{D} 6,1 \mathrm{~A} 2$ & \\
\hline Clomipramine & 10-200, max $250(25)$ & $17-28$ & $2 \mathrm{D} 6,1 \mathrm{~A} 2$ & \\
\hline Desipramine & 100-200, max $300(25)$ & 24 & $2 \mathrm{D} 6,1 \mathrm{~A} 2$ & $\begin{array}{l}\text { As effect of class: } \downarrow \alpha 2 \text {-Agonists } \\
(50,55,57), \uparrow \text { Propranolol (57), }\end{array}$ \\
\hline Nortriptyline & 70-150, max 300 (25) & 36 & 2D6 & $\downarrow$ Calcium Antagonists (57) \\
\hline Doxepin & 75-150, max 300 (25) & 24 & 2D6 & \\
\hline Trimipramine & 50-150, max $300(25)$ & $7-24$ & 2D6, 2D19, $2 \mathrm{C9}$ & \\
\hline Protriptyline & 15-40, max 60 (15) & 74 & 2D6 & \\
\hline Maprotiline & 70-150, max 225 (25) & 51 & 2D6 & \\
\hline \multicolumn{5}{|l|}{ MAOI } \\
\hline Tranylcypromine & $30-60(10)$ & 240 & $2 \mathrm{~A} 6$ & \\
\hline Phenelzine & 45-75, max 90 (15) & 240 & - & $\begin{array}{l}\text { The first three drugs: } \downarrow \alpha 2 \text {-Agonists } \\
(55,57), \uparrow \text { Propranolol }(57)\end{array}$ \\
\hline Selegiline patch & $6-12(6)$ & 24 & 2B6, 2D6, 3A4 & \\
\hline Isocarboxazid & 40-60 (20) & 240 & - & \\
\hline Moclobemide & $300-600(300)$ & 24 & 2C19, 2D6 & \\
\hline
\end{tabular}

$\uparrow=$ increasing action, $\downarrow=$ reduced action of the drug.

hypertensive subjects were treated with amlodipine (75). Nonsignificant effects of citalopram on $\mathrm{BP}$ levels $(<1 \mathrm{mmHg})$ were also reported in a similar group of geriatric patients
(76). Escitalopram in hypertensive and depressed individuals younger than 65 years did not show significant effects on BP (difference $<1 \mathrm{mmHg}$ ), but a decrease in $\mathrm{HR}(7 \mathrm{bpm})$ was 
TABLE 2 | Influence of antidepressant drugs on blood pressure and heart rate.

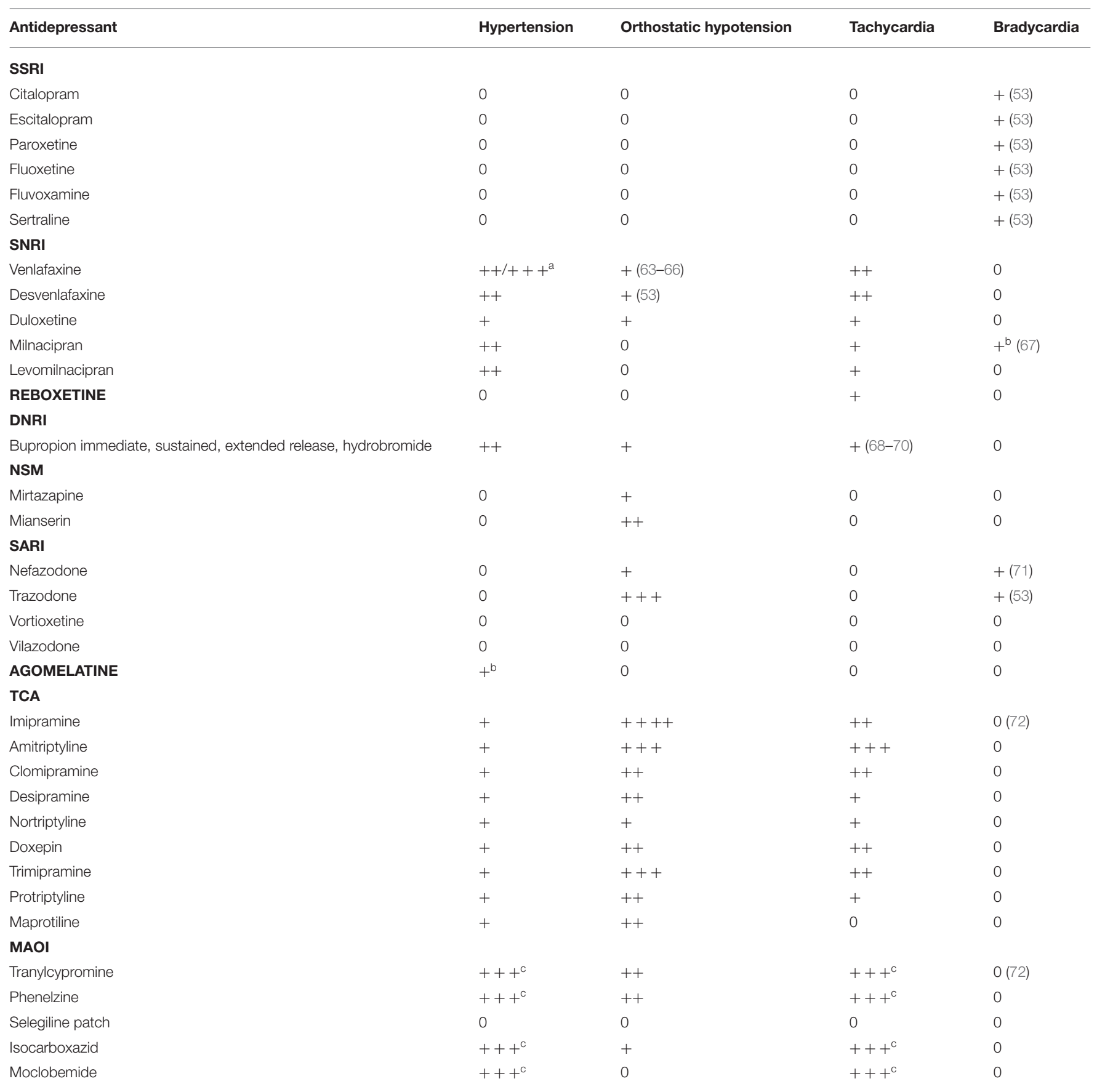

Effects: $++++=$ high,$+++=$ moderate, $++=$ low, $+=$ very low, $0=$ none; ${ }^{a}$ Dose higher than 225 mg/day; ${ }^{b}$ Overdose; ${ }^{c}$ When co-administered with tyramine-containing food.

reported (77). Escitalopram, citalopram, and the other SSRIs (fluoxetine, sertraline, and paroxetine) did not significantly change BP levels in young depressed female patients without any other metabolic or hypertensive comorbidities $(<3 \mathrm{mmHg})$ (78). Paroxetine, different from other SSRIs, is characterized by a mild anticholinergic and inhibitory effect on the NE transporter (NET). In depressed patients with ischemic heart disease, however, paroxetine did not show significant effects on
$\mathrm{HR}$, conduction intervals or ventricular arrhythmias, diastolic supine and standing BP, and standing systolic BP. However, a significant increase in supine systolic BP $(4 \mathrm{mmHg})$ was observed after 6 weeks of treatments (79). In mentally healthy subjects with a history of coronary disease undergoing periods of psychological stress, paroxetine lowered systolic and diastolic BP by $10-15 \%$ from baseline levels in non-stressful times (80). Similar results were observed in active smokers $(5-\mathrm{mmHg}$ reduction of systolic 
BP) (81). Its adverse effects are similar to other SSRIs, but as a weak antimuscarinic drug, constipation, dry mouth, and sedation are reported. Patients with renal and hepatic impairment should be administered a lower dose when titrating the drug. Paroxetine has a relevant inhibitory capacity on CYP2D6 metabolic activity and, when combined with metoprolol, can significantly increase metoprolol circulating levels (3- to 5-fold) and reduce the HR and systolic BP of patients, both in rest and exercise state. Therefore, a dose adjustment, close monitoring of the metoprolol-related adverse effects, or a change in the antidepressant drug is needed (Table 1).

\section{Sertraline, Fluvoxamine, and Fluoxetine}

Sertraline, a widely used SSRI, has a moderate ability to block the DA reuptake transporter. This leads to increased DA neurotransmission, which might contribute to its therapeutic action. Normally, increasing the levels of 5-HT is accompanied by reductions in DA release. In addition to effects on 5-HT and DA pathways, some SSRIs, including sertraline, fluvoxamine, escitalopram, and citalopram but not paroxetine, possess a high-to-moderate affinity for the sigma-1 receptor, suggesting that some of their antidepressant effects may depend on this pathway. Sigma-1 receptors have been found in limbic and other cerebral endocrine areas such as the hippocampus, frontal cortex, and hypothalamus, which have been implicated in the pathophysiology of depression (82). Sigma receptors were initially considered a subclass of the sigma opioid receptors and included two subtypes: sigma-1 and sigma-2. Animal and human studies show that agonists of the sigma-1 receptor cause vasodilation and systolic BP fall due to nitric oxide release from endothelial and neuronal nitric oxide synthases. This suggests a potential application of sigma agonists in antihypertensive drug treatments $(83,84)$. Such effects may be especially relevant for fluvoxamine, fluoxetine, and escitalopram, which are strong agonists of the sigma-1 receptor but not sertraline, which, despite a high affinity for the sigma-1 receptor, only acts as a mild antagonist, making its effect on BP overall low (83). In fact, sertraline rarely causes arterial hypotension and is considered safe even in patients with recent myocardial infarction or unstable angina. Sertraline was indistinguishable from placebo across all surrogate measures of cardiovascular safety, including change in BP (not significant increases of 3 and $2 \mathrm{mmHg}$ for systolic and diastolic BP levels, respectively), $\mathrm{HR}$, arrhythmias, and left ventricular ejection fraction (85). Sertraline was found to be safe, well-tolerated, and effective even in elderly patients suffering from hypertension and other forms of vascular comorbidity: a significant increase in both standing systolic $(+6.5 \mathrm{mmHg})$ and diastolic $\mathrm{BP}(+3.8 \mathrm{mmHg})$ but not in supine BP (86). Fluvoxamine, possibly acting on sigma-1 receptors, can induce sedation and fatigue in some patients but usually does not cause postural hypotension nor other significant cardiac effects except for slight bradycardia. Similarly, it carries a very low risk of QT interval prolongation (87). Fluoxetine, in addition to SSRI effects, has antagonist effects on $5-\mathrm{HT}_{2 \mathrm{C}}$ receptors, which could lead to increases in both $\mathrm{NE}$ and DA neurotransmissions. A modest reduction in sitting and standing systolic $(-2.9$ and $-2.6 \mathrm{mmHg})$ and diastolic BP
$(-2.3$ and $-1.5 \mathrm{mmHg})$ was observed after short periods (12 weeks) of treatment with fluoxetine in major depressive patients normotensive and hypertensive. A diversified pattern between hypertensive and normotensive subgroups was reported with hypertensive (diastolic BP between 90 and $95 \mathrm{mmHg}$ ) patients showing a larger $\mathrm{BP}$ reduction $(-4.3$ and $-5.6 \mathrm{mmHg}$ sitting and standing systolic BP and -4.8 and $-3.9 \mathrm{mmHg}$ for diastolic BP) than in normotensive with pretreatment diastolic BP values between 60 and $90 \mathrm{mmHg}(-4.3$ and $-5.6 \mathrm{mmHg}$ sitting and standing systolic BP and -4.8 and $-3.9 \mathrm{mmHg}$ for diastolic $\mathrm{BP})$. The normotensive subjects with pretreatment diastolic BP $<60 \mathrm{mmHg}$ had a modest increase in BP levels instead (88). Moreover, fluoxetine does not cause changes in BP in patients with depression and recent myocardial infarction (89). Sertraline, fluvoxamine, and fluoxetine do not require dose adjustments in patients with impaired renal function, but it may be necessary to reduce doses in those with hepatic impairments. In a large meta-analysis evaluating the effect of SSRIs on BP in depressed patients, no significant differences in systolic and diastolic BP were observed vs. placebo. No statistical difference was also reported for five widely used SSRIs (paroxetine, fluoxetine, sertraline, escitalopram, and citalopram) (90). In general, SSRIs did not significantly affect BP levels and are considered safe in patients with and without preexisting cardiovascular disease (Table 2) (73). A recent review confirmed the safety of the SSRI drug class but reported the risk of developing orthostatic hypotension at high dosage (91). This claim should, however, be tempered with the risk of serotoninergic syndrome, a rare potential life-threatening condition occurring when SSRIs are used at high doses or combined with other 5-HT agonists. The massive release of 5-HT leads to activation of central 5$\mathrm{HT}_{1 \mathrm{~A}}$ and $5-\mathrm{HT}_{2 \mathrm{~A}}$ receptors (92) and induces neuromuscular hyperactivity (myoclonus, hyperreflexia, and rhabdomyolysis), cognitive dysfunction (agitation and confusion), autonomic symptoms (hyperthermia, tachycardia, and hypertensive crisis), and, in rare cases, multi-organ failure syndrome (19, 92, 93). Posterior reversible encephalopathy syndrome has also been reported as a complication of severe hypertension (94). Treatments include withdrawal of the $\operatorname{drug}(\mathrm{s})$ and supportive care, benzodiazepines for the control of agitation and convulsions, cyproheptadine (a histamine-H1 and 5$\mathrm{HT}_{2 \mathrm{~A}}$ antagonist and widely used antidote for neuromuscular paralysis), and sedation and intubation in case of severe muscle rigidity and hyperthermia $(92,95)$.

\section{Serotonin-Norepinephrine Reuptake Inhibitors}

SNRIs include venlafaxine, desvenlafaxine, duloxetine, milnacipran, and levomilnacipran (Table 1). The first three compounds mainly act on serotoninergic neurons inhibiting presynaptic 5-HT, whereas milnacipran and levomilnacipran preferentially block the reuptake of NE. SNRIs can indirectly affect the dopaminergic system by increasing synaptic DA levels in the prefrontal cortex because presynaptic NET inhibition also acts on DA reuptake (55). This class of drugs may increase BP $(11,15,19)$, in particular diastolic BP $(16,90)$, through an 
increased myocardial and vascular sensitivity to sympathetic stimulation, which results in a rise in cardiac output and ultimately an increase in BP (Table 2) (96). Antidepressants, particularly SNRIs, require special caution when they are prescribed to pregnant women before the 16th week of gestation because of the risk of gestational hypertension and preeclampsia (97-99).

\section{Venlafaxine, Desvenlafaxine, and Duloxetine}

Venlafaxine is indicated as a treatment for major depressive disease, generalized anxiety disorder, panic disorder, and social anxiety disease. Its half-life is $5 \mathrm{~h}$, but its major and effective metabolite (O-desmethylvenlafaxine) has an 11-h halflife (Table 1). This metabolite has a greater effect on NET than SERT compared with the parent compound (55). The typical starting dose of venlafaxine is $37.5 \mathrm{mg}$, which, when tolerated, can be slowly increased up to $375 \mathrm{mg}$ once daily. At lower doses, the inhibition of 5-HT reuptake prevails, whereas at high doses (over $225 \mathrm{mg}$ ) venlafaxine mainly acts as a NE reuptake inhibitor $(100,101)$. Desvenlafaxine can block both 5-HT and NE reuptake at low doses $(102,103)$. The immediate-release formulation of venlafaxine can induce sustained diastolic hypertension in $10-15 \%$ of patients with a lower risk of raising BP with the extended-release formulation. The extended-release formulation of venlafaxine has been related to BP elevation in almost $6 \%$ of patients, whereas orthostatic hypotension is even three times more frequent; it ought to be noted that two of three of those who developed orthostatic hypotension took cardiovascular drugs, and $44 \%$ were treated with benzodiazepines (104). Chronic venlafaxine treatment not only determines a sustained increase in BP (diastolic BP increase up to $15 \mathrm{mmHg}$ ) (105) but can also facilitate the occurrence of hypertensive crisis in normotensive patients as well $(53,106-108)$. It has been shown that venlafaxine does not worsen preexisting hypertension but causes a rise in BP in normotensive patients (109). Desvenlafaxine, even at low doses, can increase HR and BP (0.66-3.41-mmHg rise in supine diastolic $\mathrm{BP}$ and $2-\mathrm{mmHg}$ rise in supine systolic BP at lower doses) $(102,110)$. Moreover, the incidence of hypertensive crisis is described in adults $(53,103)$ but not in children and adolescents (111). Posterior reversible encephalopathy syndrome has also been described as a result of severe hypertension after starting moderate doses of venlafaxine (112). Because of a potential increase in BP, venlafaxine has also been used to treat symptomatic hypotension (113), even if its use is not approved for the treatment of orthostatic hypotension in the last 2017 American College of Cardiology/American Heart Association/Heart Rhythm Society Syncope Guidelines and 2018 European Society of Cardiology Guidelines for the diagnosis and management of syncope $(114,115)$.

Duloxetine is prescribed for major depressive disorder as well as diabetic peripheral neuropathic pain, chronic musculoskeletal pain, and fibromyalgia (116). Duloxetine can increase HR and systolic and diastolic BP (+1.89 $\mathrm{mmHg}$ of diastolic BP) (117-119); a marked increase in BP levels was reported when supratherapeutic doses were used $(+12 \mathrm{mmHg}$ for systolic BP and $+7 \mathrm{mmHg}$ for diastolic BP) (90). Less than $1 \%$ of patients develop hypertensive crises with duloxetine (53). However, it was also reported that the effect of duloxetine on BP is clinically negligible $(<1-\mathrm{mmHg}$ rise for both diastolic and systolic BP) in another study, indicating this drug as a safe option for patients with cardiovascular disease (120). Sporadic Takotsubo cardiomyopathy has also been reported after duloxetine and venlafaxine use $(121,122)$. Venlafaxine and duloxetine treatment has also been correlated to orthostatic hypotension in young and old patients at therapeutic doses $(63,123-125)$. Increased synaptic NE levels by venlafaxine or duloxetine can stimulate presynaptic $\alpha-2$ adrenergic receptors, thus reducing NE release from the nerve terminals. Alpha-2 adrenergic receptors are polymorphic, and some specific genetic variants show a higher propensity for reduced NE release from the nerve endings after activation of $\alpha-2$ adrenergic receptors (126-128). In addition, higher plasma venlafaxine levels are found in the poor metabolizer genotype CYP2D6, leading to sustained stimulation of $\alpha-2$ adrenergic receptors by NE (125). Both these mechanisms may participate in causing orthostatic hypotension (Table 2).

A recent review shows a low risk for venlafaxine to induce a rise in $\mathrm{BP}$, and, on the contrary, a decreased or neutral effect of this drug on BP was reported more frequently (124). Another study confirmed no effect on the cardiovascular system by venlafaxine in geriatric patients (76).

\section{Milnacipran and Levomilnacipran}

Milnacipran is prescribed not only for major depressive disease but also for fibromyalgia, and it can be an effective treatment for chronic fatigue syndrome and anxiety (Table 1) (129). Levomilnacipran is the enantiomer of the racemic drug, milnacipran, and its affinity for NET is higher than other SNRIs (with a NET/5-HT transporter ratio of 1.5 in humans) (130). Its serotoninergic activity increases when administered at higher doses (131). Milnacipran and levomilnacipran are contraindicated in end-stage kidney disease and chronic liver disease and patients with previous cardiovascular disease. Milnacipran and levomilnacipran can induce an increase in both systolic and diastolic BP $(+3$ and $+3.2 \mathrm{mmHg}$ in systolic and diastolic BP, respectively, for levomilnacipran, and $+3 \mathrm{mmHg}$ for both in systolic and diastolic BP with milnacipran) (132137) as observed during office and ambulatory BP monitoring (138-140). Takotsubo cardiomyopathy has been described at both therapeutic doses and in overdoses of milnacipran; high doses of this drug show negative inotropic, chronotropic, and dromotropic effects $(67,141)$.

\section{Selective Norepinephrine Reuptake Inhibition}

Reboxetine is prescribed for major depressive disease, dysthymia, and attention-deficit/hyperactivity disorder, with better tolerability than TCA (Table 1) (142). Its antidepressant effects relate to the sustained increase in NE levels in the central nervous system $(143,144)$. The effects of reboxetine on the cardiovascular system are diverse when comparing acute with chronic treatments. Reboxetine has a highly selective action on NET, a lower affinity on muscarinic, histamine-H1, and adrenergic $\alpha 1$ receptors (145) and can increase DA levels through presynaptic NET inhibition (143). Neutral effects on 
BP have been reported in long-term treatment with reboxetine (Table 2) (142, 146), whereas a transient BP reduction has been reported after acute administration $(-2.1 \mathrm{mmHg})(147)$. In fact, acute administration of reboxetine can lower BP by presynaptic $\alpha 2$-adrenoceptor stimulation resulting in NE release inhibition (147). Desensitization of $\alpha 2$-adrenoceptors occurs after long-term treatment, thus facilitating NE release $(143,147)$ and leading to reduced sympathetic outflow and neutral effects on BP in both human and animal studies $(144,147)$. In shortterm studies, reboxetine has been associated with an increase in HR $(148,149)$. A few studies in healthy subjects reported an increase in systolic $(8 \mathrm{mmHg})$ and diastolic $\mathrm{BP}(4 \mathrm{mmHg})$ after reboxetine administration (148-150); conversely, arterial hypotension is observed in up to $12 \%$ of depressed patients (151). In addition, it is reported that long-term reboxetine treatment showed a decrease in systolic BP levels in patients with metabolic syndrome but an increase in lean and healthy controls (152). Therefore, the cardiovascular effects of reboxetine are variable in relation to acute or prolonged administration; even in prolonged treatment where the main results indicate a neutral effect on BP, modest phenomena of both hypotension and arterial hypertension can be observed while still considering the drug a safe option $(144,147)$.

In fact, according to the UK Medicines and Healthcare Products Regulatory Agency and the European Medicines Agency, both hypotension and hypertension have been reported as common undesirable effects observed in post-marketing data ${ }^{1}$.

Atomoxetine is a selective inhibitor of NET and is prescribed in clinical practice for attention-deficit/hyperactivity disorder and in neurogenic orthostatic hypotension of multisystemic atrophy because of its ability to increase BP (153).

\section{Dopamine-Norepinephrine Reuptake Inhibitor}

Bupropion is a unicyclic aminoketone drug that enhances the release of NE and DA through NET and DAT inhibition. It is used to treat major depressive disease and for smoking cessation because of its activity as a non-competitive antagonist of nicotinic acetylcholine receptors. Because of renal and hepatic elimination, low doses should be used in patients with renal or hepatic failure (Table 1). Elevated plasma concentrations of bupropion can also lower epileptic thresholds. Chronic bupropion treatment causes a significant rise in diastolic BP in depressed outpatients $(+7$ $\mathrm{mmHg}$ ) (154), whereas, in hospitalized smokers with an acute cardiovascular disease, no statistically significant differences were observed in both systolic $(+8.7 \mathrm{mmHg})$ and diastolic $\mathrm{BP}(+7.4$ $\mathrm{mmHg}$ ) when compared with placebo (Table 2) (155). A neutral effect was reported in other studies $(156,157)$. When patients were treated with high doses (300-400 mg/day), a significant rise in BP was observed instead (68). In cases of bupropion overdoses, hypertension developed in 1 to $4 \%$ of patients, whereas hypotension was reported in 1-2\% (158). Bupropion poisoning was linked to mild hypertension in 56\% of cases (69). There is also a report of supine hypertension $(+5 \mathrm{mmHg}$

${ }^{1}$ https://www.medicines.org.uk/EMC/medicine/8386/SPC/Reboxetine/\#gref. for systolic and $+3 \mathrm{mmHg}$ for diastolic BP) associated with orthostatic hypotension (with a mean decrease of $4 \mathrm{mmHg}$, up to a maximum value of $-40 \mathrm{mmHg}$ ) after bupropion treatment in depressed coronary heart disease patients (159).

\section{Norepinephrine-Serotonin Modulators}

Mirtazapine is approved for the treatment of major depressive and generalized anxiety disorders. It is frequently prescribed at bedtime because of its efficacy in sleep induction. It acts as an $\alpha 2$-adrenergic, 5- $\mathrm{HT}_{2 \mathrm{~A}}, 5-\mathrm{HT}_{2} \mathrm{C}, 5-\mathrm{HT}_{3}$, histamine- $\mathrm{H} 1$, and $\mathrm{H} 2$ receptor antagonist. It should be prescribed with caution in case of renal, cardiac, and hepatic impairments (Table 1). Mianserin has a tetracyclic structure and has the same pharmacological profile as mirtazapine but with a more pronounced antagonism of $\alpha 1$-adrenergic receptors activity (Table 1) (160). Both drugs can induce weight gain, but orthostatic hypotension is more frequent with mianserin (fall in BP up to $25 \mathrm{mmHg}$ in hypertensive patients) $(91,160,161)$. Although mirtazapine is reported to determine orthostatic hypotension in $7 \%$ of treated patients (162), there are also other studies in the literature showing no effect on BP $(163,164)$. It has been recently considered a safe drug for cardiovascular patients (124). Mianserin, by decreasing total vascular resistance, is often responsible for decreasing systolic and diastolic BP while standing (165), even if the neutral effect on BP changes is also reported $(166,167)$. Orthostatic hypotension is less common if the dosage of mianserin is raised gradually (168), in contrast, to rapidly increasing the dose (until $60 \mathrm{mg}$ ), which can induce a marked reduction in BP (Table 2) (169).

\section{Serotonin Agonist/Antagonist-Reuptake Inhibitors}

Nefazodone, trazodone, vortioxetine, and vilazodone act as agonist/antagonist of 5-HT receptors and SERT inhibitors (Table 1). Nefazodone is prescribed for major depressive disorders, and its activity is related to $5-\mathrm{HT}_{2 \mathrm{~A}}$ receptor antagonism and on SERT inhibition (55). Nefazodone and its major metabolite hydroxyl-nefazodone pose several safety concerns, particularly liver toxicity. A reduction in systolic BP (up to $-7 \mathrm{mmHg}$ at higher doses) and HR has been reported in patients treated chronically (at least 3 weeks) with nefazodone via serotonin-mediated inhibition of sympathetic cardiac and vascular tone (Table 2) (170). In experimental models, 5-HT reduces $\mathrm{HR}$ via a centrally related increase in vagal tone by $5-\mathrm{HT}_{1 \mathrm{~A}}$ receptor stimulation, post-ganglionic cholinergic nerve endings by $5-\mathrm{HT}_{3}$ receptor activation, and through the presynaptic inhibition of sympathetic drive (170). In case of overdoses, BP changes are not frequent: arterial hypotension affects up to $1.6 \%$ of cases, whereas hypertension is rarer $(0.4 \%)(71)$.

Trazodone is used at low doses for insomnia, especially among the elderly, whereas its antidepressant activity appears at higher doses (150 mg/day). At low doses, trazodone acts mainly as a potent $5-\mathrm{HT}_{2 \mathrm{~A}}$ receptor antagonist but a low $\mathrm{H} 1$ histamine receptor and $\alpha 1$-adrenergic antagonist; at high doses, SERT inhibition and $5-\mathrm{HT}_{2} \mathrm{C}$ antagonism are the drug's targets $(55,171)$. Caution should be used in patients with hepatic or 
cardiac dysfunction because of potential arrhythmogenic effects (QT prolongation). A case of fatal overdose due to torsades de pointes was also reported (172). Orthostatic hypotension occurs when elderly or patients with preexisting heart disease are treated with trazodone and is related to $\alpha 1$-adrenergic antagonism (171, $173,174)$. Severe hypotension, even unresponsive to volume repletion, is described in cases of drug overdoses (over $2 \mathrm{~g}$ ) (Table 2) (175).

Vortioxetine is a recently marketed antidepressant, which is indicated for major depression, particularly when associated with cognitive dysfunction (Table 1). It acts in multimodal ways, being a $5-\mathrm{HT}_{3}, 5-\mathrm{HT}_{7}$, and $5-\mathrm{HT}_{1 \mathrm{D}}$ receptor antagonist, a 5$\mathrm{HT}_{1 \mathrm{~B}}$ partial agonist, a $5-\mathrm{HT}_{1 \mathrm{~A}}$ receptor full agonist, and a SERT inhibitor. Vilazodone, another antidepressant launched 7 years ago, is a $5-\mathrm{HT}_{1 \mathrm{~A}}$ partial agonist and a SERT inhibitor; it is indicated for major depressive disorders, anxiety disorder, and obsessive-compulsive disorder (Table 1). Concerning their cardiac and vascular profiles, vortioxetine and vilazodone are considered safe, with non-relevant effects on BP and a cardiovascular profile comparable with placebo (Table 2) (55, 176-180).

\section{Serotonin Antagonist-Melatonin Agonist}

Agomelatine is a melatonin receptor, MT1 and MT2 agonists, and a $5-\mathrm{HT}_{2 \mathrm{~B}} / 5-\mathrm{HT}_{2 \mathrm{C}}$ receptor antagonist prescribed for depression. It is proven to be effective at relieving the sleep disturbances that are often associated with depression (Table 1). In fact, its action on MT1 and MT2 receptors located in the suprachiasmatic nucleus of the hypothalamus can regulate the circadian rhythm and influence the autonomic output to the cardiovascular system. Its antagonism of $5-\mathrm{HT}_{2 \mathrm{~B}} / 5-\mathrm{HT}_{2} \mathrm{C}$ receptors contributes to suppressing the secretion of melatonin by the pineal gland during light hours (55). Its use can be complicated by hepatotoxicity at high doses. Agomelatine seems to be a safe drug from a cardiovascular point of view (124) and has several beneficial anti-inflammatory, antioxidant, and antihypertensive properties (91). Similarly, chronic evening treatment with melatonin, which is closely structurally related to agomelatine, reduces daytime $\mathrm{BP}$ of hypertensive patients and induces coronary vasodilation $(62,181,182)$. However, a few reports indicate an increase in BP when high doses are administered or in slow cytochrome P450 2C19 metabolizers (Table 2) (183).

\section{Tricyclic and Tetracyclic Drugs}

These drugs are used to treat depression, panic attacks, generalized anxiety disorder, post-traumatic stress disorder, bulimia nervosa, smoking cessation, and chronic pain states. Because their mechanism action targets multiple pathways (mainly acting as SERT and NET inhibitors and/or as H1-histamine, $\alpha 1$-adrenergic, $5-\mathrm{HT}_{2}$, and M1-cholinergic receptor antagonists), a wide spectrum of adverse effects can complicate their use. Tricyclic compounds include imipramine, amitriptyline, clomipramine, doxepin, trimipramine, desipramine, nortriptyline, and protriptyline (Table 1). The tetracyclic maprotiline differs from the others because of an adjunctive ring in the central structure (Table 1). They can affect $\mathrm{BP}$ levels by various mechanisms. First, the increase in systolic and diastolic BP levels has been ascribed to the anticholinergic effects of these drugs $(16,53)$. Orthostatic hypotension, however, is reported more often than increased $\mathrm{BP}$ and relates to their antagonism of $\alpha 1$-adrenergic receptors (Table 2) (124, 184-190). The increased occurrence of falls in the elderly treated with TCA can be attributed to orthostatic hypotension combined with sedation linked to the histamine-H1 receptor antagonism effect of the drugs (184). Arterial hypotension, not only orthostatic hypotension, is explained in chronic users of TCA by the downregulation of postsynaptic $\beta$-adrenergic receptors and their reduced responsiveness to catecholamines (191). However, long-term TCA therapy is also characterized by lower presynaptic $\alpha 2$-adrenergic receptor sensitivity (192), interfering with the hypotensive effect of the antihypertensive $\alpha-2$ adrenergic agonist clonidine (Table 1) (52). In the case of TCA overdose, arterial hypotension represents a major clinical concern (Table 2) (193, 194): decrease in myocardial contractility, excessive vasodilation of resistant arteries (195), central nervous system depression, and decreased neuronal firing rate via presynaptic negative feedback mechanisms on NE release (196) are all involved. Severe hypotension can be treated with fluid resuscitation and alkalization or, if necessary, by using amine vasopressors (193). Other classes of antidepressants are preferred to TCA because of a safer cardiovascular profile; TCA not only shows changes in BP but can also facilitate arrhythmias, QT interval prolongation, and heart failure (197).

\section{Imipramine, Amitriptyline, Clomipramine, Desipramine, Doxepin, and Protriptyline}

Imipramine is the oldest drug in this class. It elicits a more potent action than amitriptyline as a SERT than as a NET inhibitor. Orthostatic hypotension is an important complication of imipramine (-26 mmHg of systolic BP) (198200), amitriptyline, clomipramine (with a decrease of systolic $\mathrm{BP}$ of 5-10 $\mathrm{mmHg}$ ), and its metabolite, desmethylclomipramine (201, 202), especially in older patients (203) and when doses are rapidly up-titrated (Table 2) (202, 204-206). However, other reports found no changes, or only minor effects (149, 207, 208), and even an increase in supine BP mainly after longterm treatment (209). Desipramine, nortriptyline (the active metabolite of amitriptyline), protriptyline, and maprotiline inhibit NET more than SERT. No significant effects on sitting BP levels were reported with these drugs, even if attention should be paid to the occurrence of orthostatic hypotension $(-10$ and $-7.7 \mathrm{mmHg}$ for systolic BP for hypertensive and normotensive patients treated with nortriptyline) (198, 210213) and reduced clonidine-mediated antihypertensive effects (Table 1) (211). In experimental models of hypertension, it appears that changes in desipramine sensitivity to inhibit NET between prehypertensive and hypertensive phases can contribute to the rise in BP observed in the later phase (214). Doxepin and trimipramine act as both 5 -HT and NE reuptake blockers but with a major effect on serotoninergic activity. Amitriptyline, clomipramine, doxepin, and nortriptyline have an $\alpha 1$-adrenergic receptor antagonist effect similar to the antihypertensive drug doxazosin, thus explaining the possible orthostatic hypotension 
TABLE 3 | Dietary guidelines for patients treated with MAOls and drugs that boost norepinephrine, must to be used cautiously in patients taking MAOIs.

\begin{tabular}{ll}
\hline $\begin{array}{l}\text { Foods to avoid (not } \\
\text { necessary if } \mathbf{~ m g} \\
\text { transdermal Selegiline } \\
\text { is used) }\end{array}$ & Drugs to used cautiously \\
\hline Aged cheese & Decongestants (phenylephrine, pseudoephedrine) \\
Broad bean pods & $\begin{array}{l}\text { Stimulants (amphetamine, methamphetamine, } \\
\text { cocaine, modafinil) }\end{array}$ \\
Banana peel & $\begin{array}{l}\text { Antidepressants releasing NE (SNRI, reboxetine, } \\
\text { TCA) }\end{array}$ \\
$\begin{array}{l}\text { Dried, aged, smoked fish } \\
\text { Soy product/tofu }\end{array}$ & $\begin{array}{l}\text { Local anesthetics containing vasoconstrictors } \\
\text { Sauerkraut/kimchee }\end{array}$ \\
$\begin{array}{l}\text { Tyramine-containing } \\
\text { nutritional supplement }\end{array}$ & Phentermine \\
\hline
\end{tabular}

effect, whereas protriptyline, which exhibits weaker antagonism, has a lower orthostatic hypotension rate (Table 2) (215).

\section{Monoamine Oxidase Inhibitors}

The use of iproniazid, a non-selective, irreversible MAOI, originally prescribed for tuberculosis but found to have strong antidepressant effects, opened wide the clinical use for this class of drugs, suggesting that monoamine neurotransmission deficiencies play a central role in the development of major depression (216). Tranylcypromine, phenelzine, moclobemide, isocarboxazid, and selegiline are known as powerful antidepressants and effective agents for panic disorder and social phobia, with selegiline also being used in the early phases of Parkinson disease (Table 1). The adverse effects of MAOIs are common and consist of sexual dysfunction, constipation, sedation, dry mouth, weight gain, and insomnia, but particular concerns are the risk of "cheese reaction" and serotoninergic syndrome. The risk of developing the "cheese reaction" during treatment with MAOIs depends on the concurrent consumption of meals containing tyramine or sympathomimetic drugs (Table 3). Tyramine is normally metabolized by MAO-A located on the gut wall and by MAO-B in the liver; if MAO-A is inhibited, the bioavailability of tyramine is increased, which leads to an excess in NE, resulting in a hypertensive crisis $(55,217)$. Currently, they are not firstline antidepressant medications, and their use is limited to treatment-resistant or atypical depression.

\section{Tranylcypromine and Phenelzine}

Tranylcypromine and phenelzine are non-selective irreversible MAOI, with hepatic metabolism and renal excretion (218). Tranylcypromine and phenelzine can induce a dose-related orthostatic hypotension phenomenon (219), probably related to a relaxing effect on vascular smooth muscle (Table 2) (220). Both drugs can induce hypertensive crisis-related myocardial injury due to concomitant consumption of soft cheese (Table 3) $(221,222)$. Patients with hepatic and cardiac disease should avoid both drugs. Phenelzine induces more weight gain and sedation than other MAOIs.

\section{Selegiline}

Selegiline is a selective MAO-B at low doses and a non-selective MAOI at higher doses; it also induces dopaminergic activity at low doses. This different action, depending on the dose, implies different use: low doses (up to $10 \mathrm{mg}$ /day) for Parkinson's disease and higher doses as antidepressant treatment (Table 1) (55). The antidepressant activity requires $>70 \%$ inhibition of MAO-A (20). Conversely, low doses of selegiline have the advantage of partial action on MAO-A, allowing for fewer dietary restrictions. The selegiline transdermal patch is used for a major depressive disorder by releasing from 6 to $12 \mathrm{mg}$ every 24 hours; such a formulation allows higher inhibition of MAO-A and $\mathrm{MAO}-\mathrm{B}$ in the brain, largely bypassing the inhibition of MAO-A in the gut $(55,223)$, and thus, no dietary restrictions are recommended when low doses are used. No significant increases in systolic BP as a result of "cheese reaction" were observed when high doses of tyramine $(75 \mathrm{mg}$, a load largely exceeding the amount of a normal meal) were tested in subjects administered a selegiline transdermal patch, supporting its safety and tolerability $(224,225)$. However, other evidence still underlies using caution and the need for dietary restriction when using 9 or $12 \mathrm{mg} /$ day via patch because of limited clinical and experimental experience (Table 3) (226). Higher doses of oral and transdermal selegiline have been linked to a major frequency of orthostatic hypotension (227). No hypertensive crisis was reported with patch administration, but a small portion of patients with preexisting hypertension showed a worse BP control (224). The same study also showed that almost $10 \%$ of patients experienced an orthostatic BP decline (with a drop of $10 \mathrm{mmHg}$ in mean BP) as compared with $6.7 \%$ in the placebo group (224), suggesting that especially in the elderly, a close BP monitoring is needed. Liver and kidney disease are not a major concern as no dosage adjustments for selegiline are required (226).

\section{Moclobemide and Isocarboxazid}

Moclobemide is a selective, reversible inhibitor of MAO-A, so the dietary restriction is not required during treatment (228230). No significant effects on BP profiles have been reported during moclobemide treatment $(124,230-232)$. On the other hand, isocarboxazid is a non-selective irreversible MAOI and is considered a risk for developing orthostatic hypotension in a dose-dependent manner, although the evidence is not ample due to its limited clinical use (Table 2) (55).

\section{CONCLUSIONS}

This narrative review summarized the available studies on the effects of antidepressants on BP. Antidepressants act on several neurotransmitter systems that have direct or indirect effects on BP regulation. Thus, antidepressant drugs might lead individuals to develop hypertension, hypotension, and orthostatic hypotension through a wide array of mechanisms. Although general considerations can be made on different classes of antidepressants, each compound ultimately shows a very 
specific profile that should be considered before clinical use. Patient characteristics are another obvious source of variability for the effects of antidepressants on BP. In sum, the neutral effect on BP is a feature of SSRI, and this class represents a safe option for patients with preexisting cardiac disease. The occurrence of orthostatic hypotension should always be considered as a real risk in serotonin agonist/antagonistreuptake inhibitor-trazodone-prescribed patients, but especially in TCA-prescribed patients, with the highest rate in those receiving imipramine and the lowest with nortriptyline. As with orthostatic hypotension, treatment with SNRI, dopamine-NE reuptake inhibitor, and MAOI should be carefully monitored in patients with preexisting hypertension due to their potential to raise $\mathrm{BP}$ and facilitate the incidence of hypertensive crisis. When prescribing an antidepressant, the clinician must carefully evaluate its risk/benefit ratio by taking into account the presence of cardiovascular and cerebrovascular diseases, as well as monitoring the effects of the chosen agents. Consideration

\section{REFERENCES}

1. World Health Organization. Depression and Other Common Mental Disorders: Global Health Estimates. (2017). Available online at: https://apps. who.int/iris/bitstream/handle/10665/254610/WHO-MSD-MER-2017.2eng.pdf (accessed February 13, 2021).

2. Smith K. Mental health: a world of depression. Nature. (2014) 515:181. doi: $10.1038 / 515180$ a

3. Meng L, Chen D, Yang Y, Zheng Y, Hui R. Depression increases the risk of hypertension incidence: a meta-analysis of prospective cohort studies. $J$ Hypertens. (2012) 30:842-51. doi: 10.1097/HJH.0b013e32835080b7

4. Patten SB, Williams JV, Lavorato DH, Campbell NR, Eliasziw M, Campbell TS. Major depression as a risk factor for high blood pressure: epidemiologic evidence from a national longitudinal study. Psychosom Med. (2009) 71:2739. doi: 10.1097/PSY.0b013e3181988e5f

5. Jonas BS, Franks P, Ingram DD. Are symptoms of anxiety and depression risk factors for hypertension? Longitudinal evidence from the National Health and Nutrition Examination Survey I Epidemiologic Follow-up Study. Arch Fam Med. (1997) 6:43-9. doi: 10.1001/archfami.6.1.43

6. Slavich GM, Sacher J. Stress, sex hormones, inflammation, and major depressive disorder: Extending Social Signal Transduction Theory of Depression to account for sex differences in mood disorders. Psychopharmacology. (2019) 236:3063-79. doi: 10.1007/s00213-019-05326-9

7. GBD 2017 Disease and Injury Incidence and Prevalence Collaborators. Global, regional, and national incidence, prevalence, and years lived with disability for 354 diseases and injuries for 195 countries and territories, 19902017: a systematic analysis for the Global Burden of Disease Study 2017. Lancet. (2018) 392:1789-858. doi: 10.1016/S0140-6736(18)32279-7

8. Kao WT, Chang CL, Lin CH, Wu SL, Lin SL, Lung FW. Gender disparity in the risk of hypertension in subjects with major depressive disorder. Front Psychiatry. (2019) 10:541. doi: 10.3389/fpsyt.2019.00541

9. Hamer M, Batty GD, Stamatakis E, Kivimaki M. The combined influence of hypertension and common mental disorder on all-cause and cardiovascular disease mortality. J Hypertens. (2010) 28:2401-6. doi: 10.1097/HJH.0b013e32833e9d7c

10. Joynt KE, Whellan DJ, O'Connor CM. Depression and cardiovascular disease: mechanisms of interaction. Biol Psychiatry. (2003) 54:248-61. doi: 10.1016/S0006-3223(03)00568-7

11. Goldstein BI, Carnethon MR, Matthews KA, McIntyre RS, Miller GE, Raghuveer G, et al. Major depressive disorder and bipolar disorder predispose youth to accelerated atherosclerosis and early cardiovascular disease: a scientific statement from the American Heart Association. Circulation. (2015) 132:965-86. doi: 10.1161/CIR.0000000000000229 must be given that an appropriate treatment for depression can ultimately reduce morbidity and mortality. Finally, SSRIs and other recent antidepressants rarely affect BP in a clinically meaningful way. Nonetheless, careful consideration must be given to patients with preexistent BP abnormalities, the elderly, and to individuals with physical comorbidities. Issues requiring particular attention include potential interactions with antihypertensive agents and factors affecting drug metabolism.

\section{AUTHOR CONTRIBUTIONS}

ACal, IV, MA, and ACab conceived and designed the review. ACal, IF, IV, MB, PC, ST, MA, and ACab collected the data and contributed to the analysis of literature data. ACal, IF, IV, MB, ST, and ACab performed the analysis of all data. ACal, IV, MB, SZ, RV, PC, MA, and ACab discussion of the results. ACal, IV, MB, and ACab wrote the paper. All authors contributed to the article and approved the submitted version.
12. Toni G, Belvederi Murri M, Piepoli M, Zanetidou S, Cabassi A, Squatrito S, et al. Physical exercise for late-life depression: effects on heart rate variability. Am J Geriatr Psychiatry. (2016) 24:989-97. doi: 10.1016/j.jagp.2016.08.005

13. Meyer CM, Armenian HK, Eaton WW, Ford DE. Incident hypertension associated with depression in the Baltimore Epidemiologic Catchment area follow-up study. J Affect Disord. (2004) 83:127-33. doi: 10.1016/j.jad.2004.06.004

14. Delaney JA, Oddson BE, Kramer H, Shea S, Psaty BM, McClelland RL. Baseline depressive symptoms are not associated with clinically important levels of incident hypertension during two years of follow-up: the multi-ethnic study of atherosclerosis. Hypertension. (2010) 55:408-14. doi: 10.1161/HYPERTENSIONAHA.109.139824

15. Crookes DM, Demmer RT, Keyes KM, Koenen KC, Suglia SF. Depressive symptoms, antidepressant use, and hypertension in young adulthood. Epidemiology. (2018) 29:547-55. doi: 10.1097/EDE.0000000000000840

16. Licht CM, de Geus EJ, Seldenrijk A, van Hout HP, Zitman FG, van Dyck R, et al. Depression is associated with decreased blood pressure, but antidepressant use increases the risk for hypertension. Hypertension. (2009) 53:631-8. doi: 10.1161/HYPERTENSIONAHA.108.126698

17. Hildrum B, Mykletun A, Stordal E, Bjelland I, Dahl AA, Holmen J. Association of low blood pressure with anxiety and depression: the NordTrøndelag Health Study. J Epidemiol Community Health. (2007) 61:53-8. doi: 10.1136/jech.2005.044966

18. Alexander SP, Christopoulos A, Davenport AP, Kelly E, Marrion NV, Peters JA, et al. The coincise guide to pharmacology 2017/18: overview. $\mathrm{Br} J$ Pharmacol. (2017) 174 (Suppl 1):S1-6. doi: 10.1111/bph.13882

19. Watts SW, Morrison SF, Davis RP, Barman SM. Serotonin and blood pressure regulation. Pharmacol Rev. (2012) 64:359-88. doi: 10.1124/pr.111.004697

20. Kaumann AJ, Levy FO. 5-hydroxytryptamine receptors in the human cardiovascular system. Pharmacol Ther. (2006) 111:674-706. doi: 10.1016/j.pharmthera.2005.12.004

21. Bagdy G, Calogero AE, Murphy DL, Szemeredi K. Serotonin agonists cause parallel activation of the sympathoadrenomedullary system and the hypothalamo-pituitary-adrenocortical axis in conscious rats. Endocrinology. (1989) 125:2664-9. doi: 10.1210/endo-125-5-2664

22. Saydoff JA, Rittenhouse PA, Carnes M, Armstrong J, Van De Kar LD, Brownfield MS. Neuroendocrine and cardiovascular effects of serotonin: selective role of brain angiotensin on vasopressin. Am J Physiol. (1996) 270:(3Pt1):E513-21. doi: 10.1152/ajpendo.1996.270. 3.E513

23. Ramage AG. Central cardiovascular regulation and 5hydroxytryptamine receptors. Brain Res Bull. (2001) 56:425-39. doi: 10.1016/S0361-9230(01)00612-8 
24. Dubini A, Bosc M, Polin V. Noradrenaline-selective versus serotoninselective antidepressant therapy: differential effects on social functioning. $J$ Psychopharmacol. (1997) 11(4 Suppl):S17-23.

25. Moret C, Briley M. The importance of norepinephrine in depression. Neuropsychiatr Dis Treat. (2011) 7(Suppl 1):9-13. doi: 10.2147/NDT.S19619

26. Belujon P, Grace AA. Dopamine system dysregulation in major depressive disorders. Int J Neuropsychopharmacol. (2017) 20:1036-46. doi: 10.1093/ijnp/pyx056

27. Grace AA. Dysregulation of the dopamine system in the pathophysiology of schizophrenia and depression. Nat Rev Neurosci. (2016) 17:524-32. doi: $10.1038 / \mathrm{nrn} .2016 .57$

28. Olivares-Hernández A, Figuero-Pérez L, Cruz-Hernandez JJ, González Sarmiento R, Usategui-Martin R, Miramontes-González JP. Dopamine receptors and the kidney: an overview of health- and pharmacological-targeted implications. Biomolecules. (2021) 11:254. doi: 10.3390/biom11020254

29. Lichtman JH, Froelicher ES, Blumenthal JA, Carney RM, Doering $\mathrm{LV}$, Frasure-Smith $\mathrm{N}$, et al. Depression as a risk factor for poor prognosis among patients with acute coronary syndrome: systematic review and recommendations: a scientific statement from the American Heart Association. Circulation. (2014) 129:1350-69. doi: 10.1161/CIR.0000000000000019

30. Vaccarino V, Badimon L, Bremner JD, Cenko E, Cubedo J, Dorobantu M, et al. Depression and coronary heart disease: 2018 position paper of the ESC working group on coronary pathophysiology and microcirculation. Eur Heart J. (2020) 41:1687-96. doi: 10.1093/eurheartj/ehy913

31. Barefoot JC, Schroll M. Symptoms of depression, acute myocardial infarction, and total mortality in a community sample. Circulation. (1996) 93:1976-80. doi: 10.1161/01.CIR.93.11.1976

32. Sgoifo A, Carnevali L, Alfonso Mde L, Amore M. Autonomic dysfunction and heart rate variability in depression. Stress. (2015) 18:343-52. doi: 10.3109/10253890.2015.1045868

33. Mestanikova A, Mestanik M, Ondrejka I, Hrtanek I, Cesnekova D, Jurko A Jr, et al. Complex cardiac vagal regulation to mental and physiological stress in adolescent major depression. J Affect Disord. (2019) 249:234-41. doi: 10.1016/j.jad.2019.01.043

34. Shao $\mathrm{M}$, Lin $\mathrm{X}$, Jiang $\mathrm{D}$, Tian $\mathrm{H}$, Xu Y, Wang L, et al. Depression and cardiovascular disease: shared molecular mechanisms and clinical implications. Psychiatry Res. (2020) 285:112802. doi: $10.1016 /$ j.psychres.2020.112802

35. Yang S, Zhang L. Glucocorticoids and vascular reactivity. Curr Vasc Pharmacol. (2004) 2:1-12. doi: 10.2174/1570161043476483

36. Bouzinova EV, Wiborg O, Aalkjaer C, Matchkov VV. Role of peripheral vascular resistance for the association between major depression and cardiovascular disease. J Cardiovasc Pharmacol. (2015) 65:299-307. doi: 10.1097/FJC.0000000000000187

37. Matthews SC, Nelesen RA, Dimsdale JE. Depressive symptoms are associated with increased systemic vascular resistance to stress. Psychosom Med. (2005) 67:509-13. doi: 10.1097/01.psy.0000160467.78373.d8

38. Rajagopalan S, Brook R, Rubenfire M, Pitt E, Young E, Pitt B. Abnormal brachial artery flow-mediated vasodilation in young adults with major depression. Am J Cardiol. (2001) 88:196-8, A7. doi: 10.1016/S0002-9149(01)01623-X

39. Smith PJ, Blumenthal JA, Babyak MA, Doraiswamy PM, Hinderliter A, Hoffman BM, et al. Intima-media thickness and age of first depressive episode. Biol Psychol. (2009) 80:361-4. doi: 10.1016/j.biopsycho.2008.11.001

40. Scuteri A, Modestino A, Fedullo F, Assisi AP, Gianni W. Depression treatment selectively modifies arterial stiffness in older participants. J Gerontol A Biol Sci Med Sci. (2013) 68:719-25. doi: 10.1093/gerona/gls230

41. Kokras N, Papadopoulou E, Georgiopoulos G, Dalla C, Petropoulos I, Kontogiannis $\mathrm{C}$, et al. The effect of treatment response on endothelial function and arterial stiffness in depression. A prospective study. J Affect Disord. (2019) 252:190-200. doi: 10.1016/j.jad.2019.04.024

42. Kessing LV, Rytgaard HC, Ekstrøm CT, Torp-Pedersen C, Berk M, Gerds TA. Antihypertensive drugs and risk of depression: a nationwide population-based study. Hypertension. (2020) 76:1263-79. doi: 10.1161/HYPERTENSIONAHA.120.15605
43. Ranchord AM, Spertus JA, Buchanan DM, Gosch KL, Chan PS. Initiation of $\beta$-blocker therapy and depression after acute myocardial infarction. Am Heart J. (2016) 174:37-42. doi: 10.1016/j.ahj.2015.11.018

44. Agustini B, Mohebbi M, Woods RL, McNeil JJ, Nelson MR, Shah RC, et al. The association of antihypertensive use and depressive symptoms in a large older population with hypertension living in Australia and the United States: a cross-sectional study. J Hum Hypertens. (2020) 34:787-94. doi: 10.1038/s41371-020-0303-y

45. Hemeryck A, Lefebvre RA, De Vriendt C, Belpaire FM. Paroxetine affects metoprolol pharmacokinetics and pharmacodynamics in healthy volunteers. Clin Pharmacol Ther. (2000) 67:283-91. doi: 10.1067/mcp.2000.104788

46. Parker RB, Soberman JE. Effects of paroxetine on the pharmacokinetics and pharmacodynamics of immediate-release and extended-release metoprolol. Pharmacotherapy. (2011) 31:630-41. doi: 10.1592/phco.31.7.630

47. Stout SM, Nielsen J, Welage LS, Shea M, Brook R, Kerber K, et al. Influence of metoprolol dosage release formulation on the pharmacokinetic drug interaction with paroxetine. J Clin Pharmacol. (2011) 51:389-96. doi: $10.1177 / 0091270010365559$

48. Flockhart DA, Tanus-Santos JE. Implications of cytochrome P450 interactions when prescribing medication for hypertension. Arch Intern Med. (2002) 162:405-12. doi: 10.1001/archinte.162.4.405

49. Coelho PV, Brum Cde A. Interactions between antidepressants and antihypertensive and glucose lowering drugs among patients in the HIPERDIA Program, Coronel Fabriciano, Minas Gerais State, Brazil. Cad Saude Publica. (2009) 25:2229-36. doi: 10.1590/S0102-311X2009001000013

50. Spina E, Scordo MG. Clinically significant drug interactions with antidepressants in the elderly. Drugs Aging. (2002) 19:299-320. doi: 10.2165/00002512-200219040-00004

51. Abrudan MB, Popa DS, Muntean DM, Gheldiu AM, Vlase L. Pharmacokinetic interactions study between carvedilol and some antidepressants in rat liver microsomes - a comparative study. Med Pharm Rep. (2019) 92:158-64. doi: 10.15386/mpr-1225

52. Spina E, Trifirò G, Caraci F. Clinically significant drug interactions with newer antidepressants. CNS Drugs. (2012) 26:39-67. doi: 10.2165/11594710-000000000-00000

53. Teply RM, Packard KA, White ND, Hilleman DE, DiNicolantonio JJ. Treatment of depression in patients with concomitant cardiac disease. Prog Cardiovasc Dis. (2016) 58:514-28. doi: 10.1016/j.pcad.2015.11.003

54. Górska D, Andrzejczak D. Influence of mianserin on the activity of some hypotensive drugs in spontaneously hypertensive rats. Pol J Pharmacol. (2003) 55:409-17.

55. Stahl SM. Essential Psychopharmacology. Neuroscientific Basis and Practical Applications. 4th ed. Cambridge: Cambridge Medicine (2013). p. 28.

56. Woroń J, Siwek M, Gorostowicz A. Adverse effects of interactions between antidepressants and medications used in treatment of cardiovascular disorders. Psychiatr Pol. (2019) 53:977-95. doi: 10.12740/PP/OnlineFirst/96286

57. Elliott WJ. Drug interactions and drugs that affect blood pressure. J Clin Hypertens. (2006) 8:731-7. doi: 10.1111/j.1524-6175.2006.05939.x

58. Cleare A, Pariante CM, Young AH, Anderson IM, Christmas D, Cowen PJ, et al. Evidence-based guidelines for treating depressive disorders with antidepressants: a revision of the 2008 British Association for Psychopharmacology guidelines. J Psychopharmacol. (2015) 29:459-525. doi: $10.1177 / 0269881115581093$

59. Meier CR, Schlienger RG, Jick H. Use of selective serotonin reuptake inhibitors and risk of developing first-time acute myocardial infarction. $\mathrm{Br}$ J Clin Pharmacol. (2001) 52:179-84. doi: 10.1046/j.0306-5251.2001.01426.x

60. Barclay TS, Lee AJ. Citalopram-associated SIADH. Ann Pharmacother. (2002) 36:1558-63. doi: 10.1345/aph.1C071

61. Bérard A, Sheehy O, Zhao JP, Vinet É, Bernatsky S, Abrahamowicz M. SSRI and SNRI use during pregnancy and the risk of persistent pulmonary hypertension of the newborn. Br J Clin Pharmacol. (2017) 83:1126-33. doi: 10.1111/bcp.13194

62. Cabassi A, Bouchard JF, Dumont EC, Girouard H, Le Jossec M, Lamontagne $\mathrm{D}$, et al. Effect of antioxidant treatments on nitrate tolerance development in normotensive and hypertensive rats. J Hypertens. (2000) 18:187-96. doi: 10.1097/00004872-200018020-00009 
63. Chikkaramanjegowda V, de Leon J. Venlafaxine-induced orthostatic hypotension in a geriatric patient. Case Rep Psychiatry. (2013) 2013:761567. doi: $10.1155 / 2013 / 761567$

64. Johnson EM, Whyte E, Mulsant BH, Pollock BG, Weber E, Begley $\mathrm{AE}$, et al. Cardiovascular changes associated with venlafaxine in the treatment of late-life depression. Am J Geriatr Psychiatry. (2006) 14:796-802. doi: 10.1097/01.JGP.0000204328.50105.b3

65. Kok R, Nolen W, Heeren T. Cardiovascular changes associated with venlafaxine in the treatment of late-life depression. Am J Geriatr Psychiatry. (2007) 15:725; author reply 726. doi: 10.1097/JGP.0b013e3180 488358

66. Duggal HS, Jagadheesan K, Nizamie HS. Venlafaxine - induced orthostatic hypotension. Indian J Psychiatry. (2001) 43:371-3.

67. Levine M, Truitt CA, O'Connor AD. Cardiotoxicity and serotonin syndrome complicating a milnacipran overdose. J Med Toxicol. (2011) 7:312-6. doi: 10.1007/s13181-011-0167-1

68. Thase ME, Haight BR, Johnson MC, Hunt T, Krishen A, Fleck RJ, et al. A randomized, double-blind, placebo-controlled study of the effect of sustained-release bupropion on blood pressure in individuals with mild untreated hypertension. J Clin Psychopharmacol. (2008) 28:302-7. doi: 10.1097/JCP.0b013e318172424e

69. Balit CR, Lynch CN, Isbister GK. Bupropion poisoning: a case series. Med J Aust. (2003) 178:61-3. doi: 10.5694/j.1326-5377.2003.tb05064.x

70. Hamilton MJ, Smith PR, Peck AW. Effects of bupropion, nomifensine and dexamphetamine on performance, subjective feelings, autonomic variables and electroencephalogram in healthy volunteers. Br J Clin Pharmacol. (1983) 15:367-74. doi: 10.1111/j.1365-2125.1983.tb01512.x

71. Benson BE, Mathiason M, Dahl B, Smith K, Foley MM, Easom LA, et al. Toxicities and outcomes associated with nefazodone poisoning: an analysis of 1,338 exposures. Am J Emerg Med. (2000) 18:587-92. doi: 10.1053/ajem.2000.9287

72. Alvar Alvarez W Jr, Pickworth KK. Safety of antidepressant drugs in the patient with cardiac disease: a review of the literature. Pharmacotherapy. (2003) 23:754-71. doi: 10.1592/phco.23.6.754.32185

73. Lespérance F, Frasure-Smith N, Koszycki D, Laliberté MA, van Zyl LT, Baker $\mathrm{B}$, et al. Effects of citalopram and interpersonal psychotherapy on depression in patients with coronary artery disease: the Canadian Cardiac Randomized Evaluation of Antidepressant and Psychotherapy Efficacy (CREATE) trial. JAMA. (2007) 297:367-79. doi: 10.1001/jama.297.4.367

74. Thase ME, Larsen KG, Reines E, Kennedy SH. The cardiovascular safety profile of escitalopram. Eur Neuropsychopharmacol. (2013) 23:1391-400. doi: 10.1016/j.euroneuro.2013.05.011

75. Fu W, Ma L, Zhao X, Li Y, Zhu H, Yang W, et al. Antidepressant medication can improve hypertension in elderly patients with depression. J Clin Neurosci. (2015) 22:1911-5. doi: 10.1016/j.jocn.2015.03.067

76. Allard P, Gram L, Timdahl K, Behnke K, Hanson M, Søgaard J. Efficacy and tolerability of venlafaxine in geriatric outpatients with major depression: a double-blind, randomised 6-month comparative trial with citalopram. Int J Geriatr Psychiatry. (2004) 19:1123-30. doi: 10.1002/gps.1190

77. Peixoto MF, Cesaretti M, Hood SD, Tavares A. Effects of SSRI medication on heart rate and blood pressure in individuals with hypertension and depression. Clin Exp Hypertens. (2019) 41:428-33. doi: 10.1080/10641963.2018.1501058

78. Beyazyüz M, Albayrak Y, Egilmez OB, Albayrak N, Beyazyüz E. Relationship between SSRIs and metabolic syndrome abnormalities in patients with generalized anxiety disorder: a prospective study. Psychiatry Investig. (2013) 10:148-54. doi: 10.4306/pi.2013.10.2.148

79. Roose SP, Laghrissi-Thode F, Kennedy JS, Nelson JC, Bigger JT Jr, Pollock BG, et al. Comparison of paroxetine and nortriptyline in depressed patients with ischemic heart disease. JAMA. (1998) 279:287-91. doi: $10.1001 /$ jama.279.4.287

80. Golding M, Kotlyar M, Carson SW, Hoyler S, Lazarus C, Davidson C, et al. Effects of paroxetine on cardiovascular response to mental stress in subjects with a history of coronary artery disease and no psychiatric diagnoses. Psychopharmacology. (2005) 182:321-6. doi: 10.1007/s00213-005-0075-7

81. Kotlyar M, al'Absi M, Thuras P, Vuchetich JP, Adson DE, Nowack $\mathrm{AL}$, et al. Effect of paroxetine on physiological response to stress and smoking. Psychosom Med. (2013) 75:236-43. doi: 10.1097/PSY.0b013e3182 $898 \mathrm{f} 6 \mathrm{~d}$

82. Alonso G, Phan V, Guillemain I, Saunier M, Legrand A, Anoal M, et al. Immunocytochemical localization of the sigma(1) receptor in the adult rat central nervous system. Neuroscience. (2000) 97:155-70. doi: 10.1016/S0306-4522(00)00014-2

83. Hashimoto K. Activation of sigma-1 receptor chaperone in the treatment of neuropsychiatric diseases and its clinical implication. J Pharmacol Sci. (2015) 127:6-9. doi: 10.1016/j.jphs.2014.11.010

84. Cohen JB, Perlis ML, Townsend RR. Systolic blood pressure as a potential target of sigma-1 receptor agonist therapy. J Clin Hypertens (Greenwich). (2018) 20:416-7. doi: 10.1111/jch.13197

85. Glassman AH, O’Connor CM, Califf RM, Swedberg K, Schwartz P, Bigger JT $\mathrm{Jr}$, et al. Sertraline treatment of major depression in patients with acute MI or unstable angina. JAMA. (2002) 288:701-9. doi: 10.1001/jama.288.6.701

86. Krishnan KR, Doraiswamy PM, Clary CM. Clinical and treatment response characteristics of late-life depression associated with vascular disease: a pooled analysis of two multicenter trials with sertraline. Prog Neuropsychopharmacol Biol Psychiatry. (2001) 25:347-61. doi: 10.1016/S0278-5846(00)00168-8

87. Funk KA, Bostwick JR. A comparison of the risk of QT prolongation among SSRIs. Ann Pharmacother. (2013) 47:1330-41. doi: $10.1177 / 1060028013501994$

88. Amsterdam JD, Garcia-Espana F, Fawcett J, Quitkin FM, Reimherr FW, Rosenbaum JF, et al. Blood pressure changes during shortterm fluoxetine treatment. J Clin Psychopharmacol. (1999) 19:9-14. doi: 10.1097/00004714-199902000-00004

89. Strik J, Honig A, Lousberg R, Lousberg A, Cheriex E, Tuynman-Qua $\mathrm{H}$, et al. Efficacy and safety of fluoxetine in the treatment of patients with major depression after first myocardial infarction: findings from a double-blind, placebo-controlled trial. Psychosom Med. (2000) 62:783-9. doi: 10.1097/00006842-200011000-00007

90. Zhong Z, Wang L, Wen X, Liu Y, Fan Y, Liu Z. A meta-analysis of effects of selective serotonin reuptake inhibitors on blood pressure in depression treatment: outcomes from placebo and serotonin and noradrenaline reuptake inhibitor controlled trials. Neuropsychiatr Dis Treat. (2017) 13:2781-96. doi: 10.2147/NDT.S141832

91. Kahl KG, Westhoff-Bleck M, Krüger THC. Effects of psychopharmacological treatment with antidepressants on the vascular system. Vascul Pharmacol. (2017) 96-8:11-8. doi: 10.1016/j.vph.2017.07.004

92. Mohammad-Zadeh LF, Moses L, Gwaltney-Brant SM. Serotonin: a review. J Vet Pharmacol Ther. (2008) 31:187-99. doi: 10.1111/j.1365-2885.2008.00944.x

93. Ott M, Mannchen JK, Jamshidi F, Werneke U. Management of severe arterial hypertension associated with serotonin syndrome: a case report analysis based on systematic review techniques. Ther Adv Psychopharmacol. (2019) 9:2045125318818814. doi: 10.1177/2045125318818814

94. Prakash S, Rathore C, Kaushikkumar R. Posterior reversible encephalopathy syndrome in a patient with serotonin syndrome. BMJ Case Rep. (2020) 13:e236450. doi: 10.1136/bcr-2020-236450

95. Graudins A, Stearman A, Chan B. Treatment of the serotonin syndrome with cyproheptadine. J Emerg Med. (1998) 16:615-9. doi: 10.1016/S0736-4679(98)00057-2

96. Dawood T, Schlaich M, Brown A, Lambert G. Depression and blood pressure control: all antidepressants are not the same. Hypertension. (2009) 54:e1. doi: 10.1161/HYPERTENSIONAHA.109.133272

97. Zakiyah N, Ter Heijne LF, Bos JH, Hak E, Postma MJ, Schuiling-Veninga CCM. Antidepressant use during pregnancy and the risk of developing gestational hypertension: a retrospective cohort study. BMC Pregnancy Childbirth. (2018) 18:187. doi: 10.1186/s12884-018-1825-y

98. Bernard N, Forest JC, Tarabulsy GM, Bujold E, Bouvier D, Giguère Y. Use of antidepressants and anxiolytics in early pregnancy and the risk of preeclampsia and gestational hypertension: a prospective study. BMC Pregnancy Childbirth. (2019) 19:146. doi: 10.1186/s12884-0192285-8

99. Toh S, Mitchell AA, Louik C, Werler MM, Chambers CD, Hernández-Díaz S. Selective serotonin reuptake inhibitor use and 
risk of gestational hypertension. Am J Psychiatry. (2009) 166:320-8. doi: 10.1176/appi.ajp.2008.08060817

100. Debonnel G, Saint-André E, Hébert C, de Montigny C, Lavoie N, Blier P. Differential physiological effects of a low dose and high doses of venlafaxine in major depression. Int J Neuropsychopharmacol. (2007) 10:5161. doi: 10.1017/S1461145705006413

101. Arakawa R, Stenkrona P, Takano A, Svensson J, Andersson M, Nag S, et al. Venlafaxine ER blocks the norepinephrine transporter in the brain of patients with major depressive disorder: a pet study using [18F]FMeNER-D2. Int J Neuropsychopharmacol. (2019) 22:278-85. doi: 10.1093/ijnp/pyz003

102. Lieberman DZ, Massey SH. Desvenlafaxine in major depressive disorder: an evidence-based review of its place in therapy. Core Evid. (2010) 4:67-82. doi: 10.2147/CE.S5998

103. Munoli RN, Praharaj SK, Bhandary RP, Selvaraj AG. Desvenlafaxine-induced worsening of hypertension. J Neuropsychiatry Clin Neurosci. (2013) 25:E2930. doi: 10.1176/appi.neuropsych.12030074

104. Wathra R, Mulsant BH, Thomson L, Goldberger KW, Lenze EJ, Karp $\mathrm{JF}$, et al. Hypertension and orthostatic hypotension with venlafaxine treatment in depressed older adults. J Psychopharmacol. (2020) 1112-8. doi: $10.1177 / 0269881120944154$

105. Carvalho AF, Sharma MS, Brunoni AR, Vieta E, Fava GA. The safety, tolerability and risks associated with the use of newer generation antidepressant drugs: a critical review of the literature. Psychother Psychosom. (2016) 85:270-88. doi: 10.1159/000447034

106. Thase ME. Effects of venlafaxine on blood pressure: a meta-analysis of original data from 3744 depressed patients. J Clin Psychiatry. (1998) 59:5028. doi: 10.4088/JCP.v59n1002

107. Kivrak Y, Güvenç TS, Akbulut N, Yagci I, Cigşar G, Gündüz S, et al. Accelerated hypertension after venlafaxine usage. Case Rep Psychiatry. (2014) 2014:659715. doi: 10.1155/2014/659715

108. Khurana RN, Baudendistel TE. Hypertensive crisis associated with venlafaxine. Am J Med. (2003) 115:676-7. doi: 10.1016/S0002-9343(03)00472-8

109. Feighner JP. Cardiovascular safety in depressed patients: focus on venlafaxine. J Clin Psychiatry. (1995) 56:574-9.

110. Liebowitz MR, Manley AL, Padmanabhan SK, Ganguly R, Tummala R, Tourian KA. Efficacy, safety, and tolerability of desvenlafaxine $50 \mathrm{mg} /$ day and $100 \mathrm{mg} /$ day in outpatients with major depressive disorder. Curr Med Res Opin. (2008) 24:1877-90. doi: 10.1185/03007990802161923

111. Findling RL, Groark J, Chiles D, Ramaker S, Yang L, Tourian KA. Safety and tolerability of desvenlafaxine in children and adolescents with major depressive disorder. J Child Adolesc Psychopharmacol. (2014) 24:201-9. doi: 10.1089/cap.2012.0126

112. Edvardsson B. Venlafaxine as single therapy associated with hypertensive encephalopathy. Springerplus. (2015) 4:97. doi: 10.1186/s40064-015-0883-0

113. Agarwal A, Ferrari P, Macmillan J, Singer R. Venlafaxine to treat severe hypotension. Nephrology. (2007) 12:622. doi: 10.1111/j.1440-1797.2007.00853.x

114. Shen WK, Sheldon RS, Benditt DG, Cohen MI, Forman DE, Goldberger $\mathrm{ZD}$, et al. 2017 ACC/AHA/HRS guideline for the evaluation and management of patients with syncope: a report of the American College of Cardiology/American Heart Association Task Force on Clinical Practice Guidelines and the Heart Rhythm Society. Circulation. (2017) 136:e60-122. doi: $10.1161 /$ CIR.0000000000000538

115. Brignole M, Moya A, de Lange FJ, Deharo JC, Elliott PM, Fanciulli A, et al. 2018 ESC guidelines for the diagnosis and management of syncope. Eur Heart J. (2018) 39:1883-948. doi: 10.5603/KP.2018.0161

116. Muscatello MRA, Zoccali RA, Pandolfo G, Mangano P, Lorusso S, Cedro C, et al. Duloxetine in psychiatric disorders: expansions beyond major depression and generalized anxiety disorder. Front Psychiatry. (2019) 10:772. doi: $10.3389 /$ fpsyt.2019.00772

117. Thase ME, Tran PV, Wiltse C, Pangallo BA, Mallinckrodt C, Detke MJ. Cardiovascular profile of duloxetine, a dual reuptake inhibitor of serotonin and norepinephrine. J Clin Psychopharmacol. (2005) 25:132-40. doi: 10.1097/01.jcp.0000155815.44338.95

118. Park K, Kim S, Ko YJ, Park BJ. Duloxetine and cardiovascular adverse events: a systematic review and meta-analysis. J Psychiatr Res. (2020) 124:109-14. doi: $10.1016 /$ j.jpsychires.2020.02.022
119. Robinson M, Oakes TM, Raskin J, Liu P, Shoemaker S, Nelson JC. Acute and long-term treatment of late-life major depressive disorder: duloxetine versus placebo. Am J Geriatr Psychiatry. (2014) 22:34-45. doi: 10.1016/j.jagp.2013.01.019

120. Hudson JI, Wohlreich MM, Kajdasz DK, Mallinckrodt CH, Watkin JG, Martynov OV. Safety and tolerability of duloxetine in the treatment of major depressive disorder: analysis of pooled data from eight placebo-controlled clinical trials. Hum Psychopharmacol. (2005) 20:327-41. doi: 10.1002/hup.696

121. Selke KJ, Dhar G, Cohn JM. Takotsubo cardiomyopathy associated with titration of duloxetine. Tex Heart Inst J. (2011) 38:573-6.

122. Christoph M, Ebner B, Stolte D, Ibrahim K, Kolschmann S, Strasser RH, et al. Broken heart syndrome: Tako Tsubo cardiomyopathy associated with an overdose of the serotonin-norepinephrine reuptake inhibitor Venlafaxine. Eur Neuropsychopharmacol. (2010) 20:594-7. doi: 10.1016/j.euroneuro.2010.03.009

123. Raskin J, Wiltse CG, Dinkel JJ, Walker DJ, Desaiah D, Katona C. Safety and tolerability of duloxetine at $60 \mathrm{mg}$ once daily in elderly patients with major depressive disorder. J Clin Psychopharmacol. (2008) 28:32-8. doi: 10.1097/jcp.0b013e318160738e

124. Behlke LM, Lenze EJ, Carney RM. The cardiovascular effects of newer antidepressants in older adults and those with or at high risk for cardiovascular diseases. CNS Drugs. (2020) 34:1133-47. doi: $10.1007 / s 40263-020-00763-\mathrm{z}$

125. Alexandrino-Silva C, Nadalini Mauá FH, de Andrade AG, de Toledo Ferraz Alves TC. Hypotension caused by therapeutic doses of venlafaxine: case report and proposed pathophysiological mechanisms. J Psychopharmacol. (2008) 22:214-6. doi: 10.1177/0269881107076403

126. Small KM, Forbes SL, Brown KM, Liggett SB. An asn to lys polymorphism in the third intracellular loop of the human alpha $2 \mathrm{~A}$-adrenergic receptor imparts enhanced agonist-promoted Gi coupling. J Biol Chem. (2000) 275:38518-23. doi: 10.1074/jbc.M004550200

127. Jewell-Motz EA, Liggett SB. An acidic motif within the third intracellular loop of the alpha2C2 adrenergic receptor is required for agonist-promoted phosphorylation and desensitization. Biochemistry. (1995) 34:11946-53. doi: $10.1021 / \mathrm{bi00037a036}$

128. Flordellis C, Manolis A, Scheinin M, Paris H. Clinical and pharmacological significance of alpha2-adrenoceptor polymorphisms in cardiovascular diseases. Int J Cardiol. (2004) 97:367-72. doi: 10.1016/j.ijcard.2003. 10.014

129. Pae CU, Marks DM, Shah M, Han C, Ham BJ, Patkar AA, et al. Milnacipran: beyond a role of antidepressant. Clin Neuropharmacol. (2009) 32:355-63. doi: 10.1097/WNF.0b013e3181ac155b

130. Auclair AL, Martel JC, Assié MB, Bardin L, Heusler P, Cussac D, et al. Levomilnacipran (F2695), a norepinephrine-preferring SNRI: profile in vitro and in models of depression and anxiety. Neuropharmacology. (2013) 70:338-47. doi: 10.1016/j.neuropharm.2013.02.024

131. Bruno A, Morabito P, Spina E, Muscatello MR. The role of levomilnacipran in the management of major depressive disorder: a comprehensive review. Curr Neuropharmacol. (2016) 14:191-9. doi: 10.2174/1570159X14666151117122458

132. Kyle JA, Dugan BD, Testerman KK. Milnacipran for treatment of fibromyalgia. Ann Pharmacother. (2010) 44:1422-9. doi: 10.1345/aph.1P218

133. Asnis GM, Henderson MA. Levomilnacipran for the treatment of major depressive disorder: a review. Neuropsychiatr Dis Treat. (2015) 11:125-35. doi: 10.2147/NDT.S54710

134. Asnis GM, Bose A, Gommoll CP, Chen C, Greenberg WM. Efficacy and safety of levomilnacipran sustained release $40 \mathrm{mg}, 80 \mathrm{mg}$, or $120 \mathrm{mg}$ in major depressive disorder: a phase 3 , randomized, double-blind, placebocontrolled study. J Clin Psychiatry. (2013) 74:242-8. doi: 10.4088/JCP. $12 \mathrm{~m} 08197$

135. Mago R, Forero G, Greenberg WM, Gommoll C, Chen C. Safety and tolerability of levomilnacipran ER in major depressive disorder: results from an open-label, 48-week extension study. Clin Drug Investig. (2013) 33:761-71. doi: 10.1007/s40261-013-0126-5

136. Sambunaris A, Bose A, Gommoll CP, Chen C, Greenberg WM, Sheehan DV. A phase III, double-blind, placebo-controlled, flexibledose study of levomilnacipran extended-release in patients with 
major depressive disorder. J Clin Psychopharmacol. (2014) 34:47-56. doi: 10.1097/JCP.0000000000000060

137. Huang Q, Zhong X, Yun Y, Yu B, Huang Y. Efficacy and safety of multiple doses of levomilnacipran extended-release for the treatment of major depressive disorder. Neuropsychiatr Dis Treat. (2016) 12:2707-14. doi: 10.2147/NDT.S114955

138. de Toledo Ferraz Alves TC, Guerra de Andrade A. Hypertension induced by regular doses of milnacipran: a case report. Pharmacopsychiatry. (2007) 40:41-2. doi: 10.1055/s-2006-958723

139. Yoshida K, Higuchi H, Takahashi H, Shimizu T. Elevation of blood pressure induced by high-dose milnacipran. Hum Psychopharmacol. (2002) 17:431. doi: 10.1002/hup.432

140. Trugman JM, Palmer RH, Ma Y. Milnacipran effects on 24-h ambulatory blood pressure and heart rate in fibromyalgia patients: a randomized, placebo-controlled, dose-escalation study. Curr Med Res Opin. (2014) 30:589-97. doi: 10.1185/03007995.2013.861812

141. Forman MB, Sutej PG, Jackson EK. Hypertension, tachycardia, and reversible cardiomyopathy temporally associated with milnacipran use. Tex Heart Inst J. (2011) 38:714-8.

142. Katona C, Bercoff E, Chiu E, Tack P, Versiani M, Woelk H. Reboxetine versus imipramine in the treatment of elderly patients with depressive disorders: a double-blind randomised trial. J Affect Disord. (1999) 55:203-13. doi: 10.1016/S0165-0327(99)00073-7

143. Invernizzi RW, Parini S, Sacchetti G, Fracasso C, Caccia S, Annoni K, et al. Chronic treatment with reboxetine by osmotic pumps facilitates its effect on extracellular noradrenaline and may desensitize alpha(2)adrenoceptors in the prefrontal cortex. Br J Pharmacol. (2001) 132:183-8. doi: 10.1038/sj.bjp.0703821

144. Fossa AA, Wisialowski TA, Cremers T, van der Hart M, Tseng E, Deng $\mathrm{S}$, et al. Improved preclinical cardiovascular therapeutic indices with longterm inhibition of norepinephrine reuptake using reboxetine. Toxicol Appl Pharmacol. (2012) 264:343-50. doi: 10.1016/j.taap.2012.09.010

145. Wong EH, Sonders MS, Amara SG, Tinholt PM, Piercey MF, Hoffmann WP, et al. Reboxetine: a pharmacologically potent, selective, and specific norepinephrine reuptake inhibitor. Biol Psychiatry. (2000) 47:818-29. doi: 10.1016/S0006-3223(99)00291-7

146. Riahi F, Tashakori A, Izadi-Mazidi S, Salehi-Veysi M. Effectiveness of reboxetine in treatment of outpatient children and adolescents with attention deficit-hyperactivity disorder with comorbid anxiety disorders. Iran $J$ Psychiatry. (2013) 8:195-200.

147. Agelink MW, Ullrich H, Baumann B, Strum S, Majewski T. Effects of reboxetine, a selective norepinephrine reuptake inhibitor, on sympathetic and parasympathetic outflow to the heart: preliminary data. Psychopharmacology. (2002) 163:151-6. doi: 10.1007/s00213-002-1146-7

148. Schroeder C, Tank J, Boschmann M, Diedrich A, Sharma AM, Biaggioni I, et al. Selective norepinephrine reuptake inhibition as a human model of orthostatic intolerance. Circulation. (2002) 105:347-53. doi: 10.1161/hc0302.102597

149. Penttilä J, Syvälahti E, Hinkka S, Kuusela T, Scheinin H. The effects of amitriptyline, citalopram and reboxetine on autonomic nervous system. A randomised placebo-controlled study on healthy volunteers. Psychopharmacology. (2001) 154:343-9. doi: 10.1007/s002130000664

150. Denolle T, Pellizzoni C, Jannuzzo MG, Poggesi I. Hemodynamic effects of reboxetine in healthy male volunteers. Clin Pharmacol Ther. (1999) 66:282-7. doi: 10.1016/S0009-9236(99)70036-6

151. Scates AC, Doraiswamy PM. Reboxetine: a selective norepinephrine reuptake inhibitor for the treatment of depression. Ann Pharmacother. (2000) 34:1302-12. doi: 10.1345/aph.19335

152. Paslakis G, Gilles M, Lederbogen F, Schilling C, Scharnholz B, Deuschle M. The effect of a 4-week treatment with reboxetine on metabolic parameters of depressed inpatients. Eur Arch Psychiatry Clin Neurosci. (2011) 261:173-7. doi: 10.1007/s00406-010-0164-4

153. Jordan J, Shibao C, Biaggioni I. Multiple system atrophy: using clinical pharmacology to reveal pathophysiology. Clin Auton Res. (2015) 25:53-9. doi: 10.1007/s10286-015-0271-4

154. Kiev A, Masco HL, Wenger TL, Johnston JA, Batey SR, Holloman LC. The cardiovascular effects of bupropion and nortriptyline in depressed outpatients. Ann Clin Psychiatry. (1994) 6:107-15. doi: $10.3109 / 10401239409148989$

155. Rigotti NA, Thorndike AN, Regan S, McKool K, Pasternak RC, Chang $\mathrm{Y}$, et al. Bupropion for smokers hospitalized with acute cardiovascular disease. Am J Med. (2006) 119:1080-7. doi: 10.1016/j.amjmed.2006. 04.024

156. Hewett K, Chrzanowski W, Jokinen R, Felgentreff R, Shrivastava RK, Gee MD, et al. Double-blind, placebo-controlled evaluation of extendedrelease bupropion in elderly patients with major depressive disorder. $J$ Psychopharmacol. (2010) 24:521-9. doi: 10.1177/0269881108100254

157. Planer D, Lev I, Elitzur Y, Sharon N, Ouzan E, Pugatsch T, et al. Bupropion for smoking cessation in patients with acute coronary syndrome. Arch Intern Med. (2011) 171:1055-60. doi: 10.1001/archinternmed.2011.72

158. Belson MG, Kelley TR. Bupropion exposures: clinical manifestations and medical outcome. J Emerg Med. (2002) 23:223-30. doi: 10.1016/S0736-4679(02)00522-X

159. Roose SP, Dalack GW, Glassman AH, Woodring S, Walsh BT, Giardina EG. Cardiovascular effects of bupropion in depressed patients with heart disease. Am J Psychiatry. (1991) 148:512-6. doi: 10.1176/ajp.148.4.512

160. Elliott HL, Whiting B, Reid JL. Assessment of the interaction between mianserin and centrally-acting antihypertensive drugs. Br J Clin Pharmacol. (1983) 15(Suppl. 2):323-8S. doi: 10.1111/j.1365-2125.1983.tb05881.x

161. Møller M, Thayssen P, Kragh-Sørensen P, Pedersen OL, Kristensen CB, Bjerre $M$, et al. Mianserin: cardiovascular effects in elderly patients. Psychopharmacology. (1983) 80:174-7. doi: 10.1007/BF00427964

162. Khawaja IS, Feinstein RE. Cardiovascular effects of selective serotonin reuptake inhibitors and other novel antidepressants. Heart Dis. (2003) 5:15360. doi: 10.1097/01.HDX.0000061695.97215.64

163. Holm KJ, Markham A. Mirtazapine: a review of its use in major depression. Drugs. (1999) 57:607-31. doi: 10.2165/00003495-199957040-00010

164. Song HR, Bahk WM, Woo YS, Jeong JH, Kwon YJ, Seo JS, et al. Efficacy and tolerability of generic mirtazapine (Mirtax) for major depressive disorder: multicenter, open-label, uncontrolled, prospective study. Clin Psychopharmacol Neurosci. (2015) 13:144-9. doi: 10.9758/cpn.2015.13.2.144

165. Jakitowicz J, Magiera P, Smoczyński S. Ocena wpływu mianseryny na wskazniki hemodynamiczne u chorych $\mathrm{z}$ depresja endogenna [Evaluation of the effect of mianserin on hemodynamic indicators in patients with endogenous depression]. Psychiatr Pol. (1991) 25:51-4.

166. Bucknall C, Brooks D, Curry PV, Bridges PK, Bouras N, Ankier SI. Mianserin and trazodone for cardiac patients with depression. Eur J Clin Pharmacol. (1988) 33:565-9. doi: 10.1007/BF00542488

167. Kopera H. Anticholinergic and blood pressure effects of mianserin, amitriptyline and placebo. Br J Clin Pharmacol. (1978) 5(Suppl. 1):29S-34S.

168. Flint AJ. Choosing appropriate antidepressant therapy in the elderly. A risk-benefit assessment of available agents. Drugs Aging. (1998) 13:269-80. doi: 10.2165/00002512-199813040-00003

169. Maguire KP, Norman TR, Burrows GD, Scoggins BA. A pharmacokinetic study of mianserin. Eur J Clin Pharmacol. (1982) 21:517-20. doi: 10.1007/BF00542048

170. Agelink MW, Majewski T, Wurthmann C, Postert T, Linka T, Rotterdam S, et al. Autonomic neurocardiac function in patients with major depression and effects of antidepressive treatment with nefazodone. J Affect Disord. (2001) 62:187-98. doi: 10.1016/S0165-0327(99)00202-5

171. Fagiolini A, Comandini A, Catena Dell'Osso M, Kasper S. Rediscovering trazodone for the treatment of major depressive disorder. CNS Drugs. (2012) 26:1033-49. doi: 10.1007/s40263-012-0010-5

172. de Meester A, Carbutti G, Gabriel L, Jacques JM. Fatal overdose with trazodone: case report and literature review. Acta Clin Belg. (2001) 56:25861. doi: $10.1179 / \mathrm{acb} .2001 .038$

173. Burgess CD, Hames TK, George CF. The electrocardiographic and anticholinergic effects of trazodone and imipramine in man. Eur J Clin Pharmacol. (1982) 23:417-21. doi: 10.1007/BF00605991

174. Glassman AH. The newer antidepressant drugs and their cardiovascular effects. Psychopharmacol Bull. (1984) 20:272-9.

175. Camacho LD, Stearns J, Amini R. Management of trazodone overdose with severe hypotension. Case Rep Emerg Med. (2019) 2019:2470592. doi: $10.1155 / 2019 / 2470592$ 
176. Baldwin DS, Chrones L, Florea I, Nielsen R, Nomikos GG, Palo $\mathrm{W}$, et al. The safety and tolerability of vortioxetine: analysis of data from randomized placebo-controlled trials and open-label extension studies. J Psychopharmacol. (2016) 30:242-52. doi: 10.1177/02698811166 28440

177. Carta MG, Pala AN, Finco G, Musu M, Moro MF. Depression and cerebrovascular disease: could vortioxetine represent a valid treatment option? Clin Pract Epidemiol Ment Health. (2015) 11:144-9. doi: 10.2174/1745017901511010144

178. Frampton JE. Vilazodone: in major depressive disorder. CNS Drugs. (2011) 25:615-27. doi: 10.2165/11207550-000000000-00000

179. Connolly KR, Thase ME. Vortioxetine: a new treatment for major depressive disorder. Expert Opin Pharmacother. (2016) 17:421-31. doi: 10.1517/14656566.2016.1133588

180. Sahli ZT, Banerjee P, Tarazi FI. The preclinical and clinical effects of vilazodone for the treatment of major depressive disorder. Expert Opin Drug Discov. (2016) 11:515-23. doi: 10.1517/17460441.2016.1160051

181. Tain YL, Lin YJ, Chan JYH, Lee CT, Hsu CN. Maternal melatonin or agomelatine therapy prevents programmed hypertension in male offspring of mother exposed to continuous light. Biol Reprod. (2017) 97:636-43. doi: 10.1093/biolre/iox115

182. Scheer FA, Van Montfrans GA, van Someren EJ, Mairuhu G, Buijs RM. Daily nighttime melatonin reduces blood pressure in male patients with essential hypertension. Hypertension. (2004) 43:192-7. doi: 10.1161/01.HYP.0000113293.15186.3b

183. Uppsala Monitoring Centre. Agomelatine and Hypertension. WHO Pharm (2014). Available online at: https://www.who.int/medicines/publications/ PharmNewsNo4_2014.pdf 13-17 (accessed February 13, 2021).

184. Darowski A, Chambers SA, Chambers DJ. Antidepressants and falls in the elderly. Drugs Aging. (2009) 26:381-94. doi: 10.2165/00002512-200926050-00002

185. Hayes JR, Born GF, Rosenbaum AH. Incidence of orthostatic hypotension in patients with primary affective disorders treated with tricyclic antidepressants. Mayo Clin Proc. (1977) 52:509-12.

186. Glassman AH, Bigger JT Jr. Cardiovascular effects of therapeutic doses of tricyclic antidepressants. A review. Arch Gen Psychiatry. (1981) 38:815-20. doi: 10.1001/archpsyc.1981.01780320095011

187. Rodriguez de la Torre B, Dreher J, Malevany I, Bagli M, Kolbinger M, Omran $\mathrm{H}$, et al. Serum levels and cardiovascular effects of tricyclic antidepressants and selective serotonin reuptake inhibitors in depressed patients. Ther Drug Monit. (2001) 23:435-40. doi: 10.1097/00007691-200108000-00019

188. Hazell P, Mirzaie M. Tricyclic drugs for depression in children and adolescents. Cochrane Database Syst Rev. (2013) 2013:CD002317. doi: 10.1002/14651858.CD002317.pub2

189. Taylor D. Antidepressant drugs and cardiovascular pathology: a clinical overview of effectiveness and safety. Acta Psychiatr Scand. (2008) 118:434-42. doi: 10.1111/j.1600-0447.2008.01260.x

190. Gaxatte C, Faraj E, Lathuillerie O, Salleron J, Deramecourt V, Pardessus $\mathrm{V}$, et al. Alcohol and psychotropic drugs: risk factors for orthostatic hypotension in elderly fallers. J Hum Hypertens. (2017) 31:299-304. doi: $10.1038 /$ jhh. 2013.82

191. Banerjee SP, Kung LS, Riggi SJ, Chanda SK. Development of beta-adrenergic receptor subsensitivity by antidepressants. Nature. (1977) 268:455-6. doi: $10.1038 / 268455 \mathrm{a} 0$

192. McMillen BA, Warnack W, German DC, Shore PA. Effects of chronic desipramine treatment on rat brain noradrenergic responses to alpha-adrenergic drugs. Eur J Pharmacol. (1980) 61:239-46. doi: 10.1016/0014-2999(80)90126-0

193. Frommer DA, Kulig KW, Marx JA, Rumack B. Tricyclic antidepressant overdose. A review. JAMA. (1987) 257:521-6. doi: 10.1001/jama.257.4.521

194. Shannon M, Merola J, Lovejoy FH Jr. Hypotension in severe tricyclic antidepressant overdose. Am J Emerg Med. (1988) 6:439-42. doi: 10.1016/0735-6757(88)90241-0

195. Kerr GW, McGuffie AC, Wilkie S. Tricyclic antidepressant overdose: a review. Emerg Med J. (2001) 18:236-41. doi: 10.1136/emj.18.4.236

196. Nybäck HV, Walters JR, Aghajanian GK, Roth RH. Tricyclic antidepressants: effects on the firing rate of brain noradrenergic neurons. Eur J Pharmacol. (1975) 32:302-12. doi: 10.1016/0014-2999(75)90297-6
197. Spindelegger CJ, Papageorgiou K, Grohmann R, Engel R, Greil W, Konstantinidis A, et al. Cardiovascular adverse reactions during antidepressant treatment: a drug surveillance report of German-speaking countries between 1993 and 2010. Int J Neuropsychopharmacol. (2014) 18:pyu080. doi: 10.1093/ijnp/pyu080

198. Thayssen P, Bjerre M, Kragh-Sørensen P, Møller M, Petersen OL, Kristensen $\mathrm{CB}$, et al. Cardiovascular effect of imipramine and nortriptyline in elderly patients. Psychopharmacology. (1981) 74:360-4. doi: 10.1007/BF0043 2748

199. Glassman AH, Bigger JT Jr, Giardina EV, Kantor SJ, Perel JM, Davies M. Clinical characteristics of imipramine-induced orthostatic hypotension. Lancet. (1979) 1:468-72. doi: 10.1016/S0140-6736(79)90824-9

200. Guelfi JD, Dreyfus JF, Pichot P. A double-blind controlled clinical trial comparing fluvoxamine with imipramine. Br J Clin Pharmacol. (1983) 15(Suppl. 3):411S-7S. doi: 10.1111/j.1365-2125.1983.tb02131.x

201. Christensen P, Thomsen HY, Pedersen OL, Gram LF, Kragh-Sørensen P. Orthostatic side effects of clomipramine and citalopram during treatment for depression. Psychopharmacology. (1985) 86:383-5. doi: 10.1007/BF00427895

202. Clomipramine dose-effect study in patients with depression: clinical end points and pharmacokinetics. Danish University Antidepressant Group (DUAG). Clin Pharmacol Ther. (1999) 66:152-65. doi: 10.1053/cp.1999.v66.99720

203. Stage KB, Kragh-Sørensen PB. Age-related adverse drug reactions to clomipramine. Acta Psychiatr Scand. (2002) 105:55-9. doi: 10.1034/j.1600-0447.2002.0_001.x

204. Joubert PH, Starke DD, Van Reenen O, Venter CP. A comparison of the cardiovascular effects and subjective tolerability of binedaline and amitriptylene in healthy volunteers. Eur J Clin Pharmacol. (1985) 27:667-70. doi: 10.1007/BF00547046

205. Mathur A, Sharma DK, Choudhary A, Jain M. Efficacy and safety of citalopram versus amitriptyline in the treatment of major depression. Indian J Psychiatry. (2005) 47:89-93. doi: 10.4103/0019-5545.55952

206. Wilson WH, Higano H, Papadatos Y, Kelwala S, Ban TA. A doubleblind placebo-controlled study to compare the autonomic effects of fluvoxamine with those of amitriptyline and doxepin in healthy volunteers. $\mathrm{Br} \quad \mathrm{J}$ Clin Pharmacol. (1983) 15(Suppl. 3):385S-92S. doi: 10.1111/j.1365-2125.1983.tb02129.x

207. Flett SR, Szabadi E, Bradshaw CM. A comparison of the effects of fluvoxamine and amitriptyline on autonomic functions in healthy volunteers. Eur J Clin Pharmacol. (1992) 42:529-33. doi: 10.1007/BF00314863

208. Ogura C, Kishimoto A, Mizukawa R, Kunimoto N, Hazama H, Ryoke K, et al. Influence of single doses of dothiepin and amitriptyline on physiological measures and psychomotor performance in normal young and elderly volunteers. Neuropsychobiology. (1983) 10:103-7. doi: 10.1159/000117994

209. Wester HA, Siegers CP. Cardiovascular effects of mianserin and amitriptyline in healthy volunteers. Int J Clin Pharmacol Ther Toxicol. (1980) 18:513-7.

210. Miller MD, Pollock BG, Rifai AH, Paradis CF, Perel JM, George C, et al. Longitudinal analysis of nortriptyline side effects in elderly depressed patients. J Geriatr Psychiatry Neurol. (1991) 4:226-30. doi: 10.1177/089198879100400409

211. Briant RH, Reid JL, Dollery CT. Interaction between clonidine and desipramine in man. Br Med J. (1973) 1:522-3. doi: 10.1136/bmj.1.5852.522

212. Roose SP, Glassman AH, Attia E, Woodring S, Giardina EG, Bigger JT Jr. Cardiovascular effects of fluoxetine in depressed patients with heart disease. Am J Psychiatry. (1998) 155:660-5. doi: 10.1176/ajp.155.5.660

213. Scalco MZ, de Almeida OP, Hachul DT, Castel S, Serro-Azul J, Wajngarten M. Comparison of risk of orthostatic hypotension in elderly depressed hypertensive women treated with nortriptyline and thiazides versus elderly depressed normotensive women treated with nortriptyline. Am J Cardiol. (2000) 85:1156-8, A9. doi: 10.1016/S0002-9149(00)00717-7

214. Cabassi A, Vinci S, Quartieri F, Moschini L, Borghetti A. Norepinephrine reuptake is impaired in skeletal muscle of hypertensive rats in vivo. Hypertension. (2001) 37(2 Pt 2):698-702. doi: 10.1161/01.HYP. 37.2.698

215. Proudman RGW, Pupo AS, Baker JG. The affinity and selectivity of $\alpha$ adrenoceptor antagonists, antidepressants, and antipsychotics for the human 
$\alpha 1 \mathrm{~A}, \alpha 1 \mathrm{~B}$, and $\alpha 1 \mathrm{D}$-adrenoceptors. Pharmacol Res Perspect. (2020) 8:e00602. doi: $10.1002 /$ prp2.602

216. Berton O, Nestler EJ. New approaches to antidepressant drug discovery: beyond monoamines. Nat Rev Neurosci. (2006) 7:137-51. doi: $10.1038 / \mathrm{nrn} 1846$

217. Cabassi A, Bergamaschi E, Mutti A, Franchini I, Borghetti A. Agerelated changes in interstitial norepinephrine. A microdialysis study in spontaneously hypertensive rats. Am J Hypertens. (1996) 9:878-83. doi: 10.1016/S0895-7061(96)00094-5

218. Ulrich S, Ricken R, Adli M. Tranylcypromine in mind (Part I): review of pharmacology. Eur Neuropsychopharmacol. (2017) 27:697-713. doi: 10.1016/j.euroneuro.2017.05.007

219. Rabkin JG, Quitkin FM, McGrath P, Harrison W, Tricamo E. Adverse reactions to monoamine oxidase inhibitors. Part II. Treatment correlates and clinical management. J Clin Psychopharmacol. (1985) 5:2-9. doi: 10.1097/00004714-198502000-00002

220. Ribback S, Pavlovic D, Herbst D, Nedeljkov-Jancic R, Wendt M, Nedeljkov $\mathrm{V}$, et al. Effects of amitriptyline, fluoxetine, tranylcypromine and venlafaxine on rat vascular smooth muscle in vitro-the role of the endothelium. J Physiol Pharmacol. (2012) 63:119-25.

221. Salter M, Kenney A. Myocardial injury from tranylcypromine-induced hypertensive crisis secondary to excessive tyramine intake. Cardiovasc Toxicol. (2018) 18:583-6. doi: 10.1007/s12012-018-9476-9

222. Ngo AS, Ho RY, Olson KR. Phenelzine-induced myocardial injury: a case report. J Med Toxicol. (2010) 6:431-4. doi: 10.1007/s13181-010-0101-y

223. Gordon MN, Muller CD, Sherman KA, Morgan DG, Azzaro AJ, Wecker L. Oral versus transdermal selegiline: antidepressantlike activity in rats. Pharmacol Biochem Behav. (1999) 63:501-6. doi: 10.1016/S0091-3057(99)00016-7

224. Robinson DS, Amsterdam JD. The selegiline transdermal system in major depressive disorder: a systematic review of safety and tolerability. J Affect Disord. (2008) 105:15-23. doi: 10.1016/j.jad.2007.04.024

225. Shulman KI, Walker SE, MacKenzie S, Knowles S. Dietary restriction, tyramine, and the use of monoamine oxidase inhibitors. J Clin Psychopharmacol. (1989) 9:397-402. doi: 10.1097/00004714-198912000-00002

226. Lee KC, Chen JJ. Transdermal selegiline for the treatment of major depressive disorder. Neuropsychiatr Dis Treat. (2007) 3:527-37.
227. Sunderland T, Cohen RM, Molchan S, Lawlor BA, Mellow AM, Newhouse PA, et al. High-dose selegiline in treatment-resistant older depressive patients. Arch Gen Psychiatry. (1994) 51:607-15. doi: 10.1001/archpsyc.1994.03950080019003

228. Bieck PR, Antonin KH, Schmidt E. Clinical pharmacology of reversible monoamine oxidase-a inhibitors. Clin Neuropharmacol. (1993) 16 Suppl 2:S34-41.

229. Haefely W, Burkard WP, Cesura AM, Kettler R, Lorez HP, Martin JR, et al. Biochemistry and pharmacology of moclobemide, a prototype RIMA. Psychopharmacology. (1992) 106:S6-14. doi: 10.1007/ BF02246225

230. Newburn GM, Fraser AR, Menkes DB, Mullen PE. A double blind trial of moclobemide versus amitriptyline in the treatment of depressive disorders. Aust N Z J Psychiatry. (1990) 24:475-9. doi: 10.3109/0004867900 9062902

231. Laux G, Philipp M, Kohnen R. Hypertension with moclobemide. Lancet. (1996) 347:1330. doi: 10.1016/S0140-6736(96)90975-7

232. Stage KB. Orthostatic side effects of clomipramine and moclobemide during treatment for depression. Nord J Psychiatry. (2005) 59:298-301. doi: 10.1080/08039480500213725

Conflict of Interest: The authors declare that the research was conducted in the absence of any commercial or financial relationships that could be construed as a potential conflict of interest.

Publisher's Note: All claims expressed in this article are solely those of the authors and do not necessarily represent those of their affiliated organizations, or those of the publisher, the editors and the reviewers. Any product that may be evaluated in this article, or claim that may be made by its manufacturer, is not guaranteed or endorsed by the publisher.

Copyright (C) 2021 Calvi, Fischetti, Verzicco, Belvederi Murri, Zanetidou, Volpi, Coghi, Tedeschi, Amore and Cabassi. This is an open-access article distributed under the terms of the Creative Commons Attribution License (CC BY). The use, distribution or reproduction in other forums is permitted, provided the original author(s) and the copyright owner(s) are credited and that the original publication in this journal is cited, in accordance with accepted academic practice. No use, distribution or reproduction is permitted which does not comply with these terms. 